\title{
الإبداعات المغربية باللغات الأجنبية \\ بين سلطة اللغة وسلطة الهوية: قراءة تراتبية
}

$$
\begin{aligned}
& \text { فؤاد بوعلي } \\
& \text { الملخص }
\end{aligned}
$$

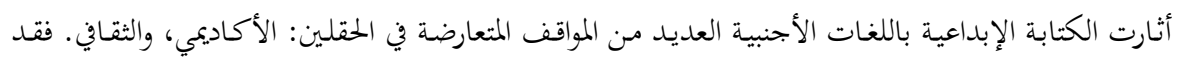

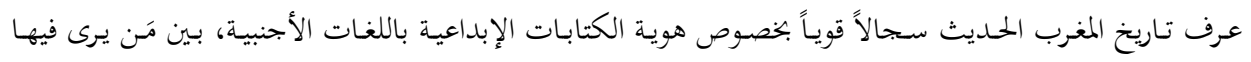

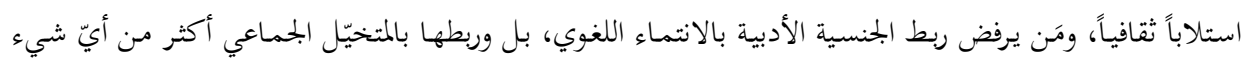

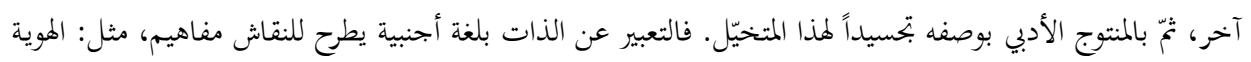

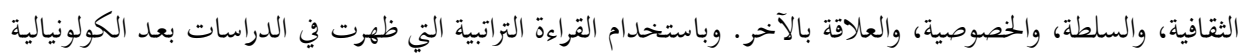

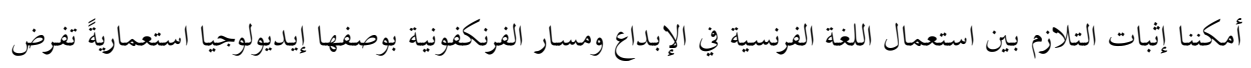

$$
\begin{aligned}
& \text { لغتها على الشعوب والفضاءات الذيلية. } \\
& \text { الكلمات المفتاحية: اللغة، الهوية، الإبداعات المغربية، هوية الأدب، اللغات الأجنبية. }
\end{aligned}
$$

\section{The Moroccan Writings in Foreign Languages Between Linguistic Authority and Identity-based Authority: A Hierarchical Reading}

\section{Abstract}

The debate over literary writing in a foreign language has instigated a lot of dichotomous points of view in Moroccan academic and cultural circles. History of modern Morocco has witnessed strong ongoing debates about the identity of creative writings in foreign language. There are those who would consider such writings as cultural alienation. Contrary to that, there are those who refuse to link literary text to language belonging, and link it instead to the collective imaginary and to the literary product as a manifestation of this imaginary. In fact, expressing the self by using a foreign language puts into question notions such as cultural identity, authority, nationbuilding, and otherness. By applying the theory of hierarchical reading which appeared in the post colonial studies, we have established the relationship between using French in creative writings and La Francophonie as a colonial ideology imposed on people and annexed spaces.

Keywords: language, identity, Moroccan writings, literary identity; foreign languages

$$
\begin{aligned}
& \text { * دكتوراه دولة في اللسانيات (جامعة محمد الأول وجدة)، أستاذ باحث في اللغويات والترجمة، وزارة الاتصال، المغرب. } \\
& \text { bouali68@gmail.com البريد الإلكتروني }
\end{aligned}
$$

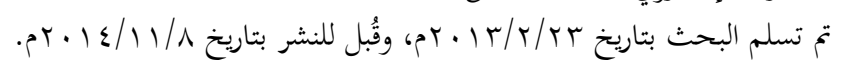




\section{مقدمة:}

يهدف هذا البحث إلى الإجابة عن التساؤل المهم الآتي: ما حدود العلاقة بين اللغة

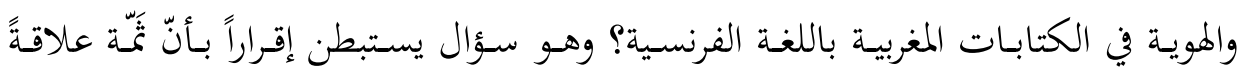

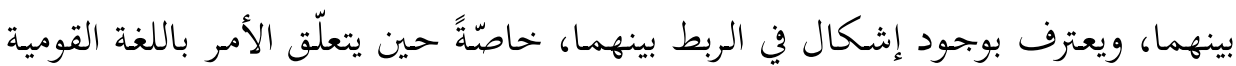
وبتحلياةا في الآداب المكتوبة باللغة الكولونيالية.

فقــد مثَّل النقـاث الـدائر حـول انتمـاء الأدب المغـربي المكتـوب باللغـات الأجنبيـة،

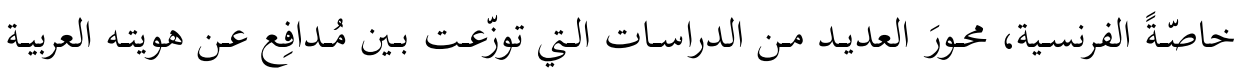
المغربية، ومَن يزعم انتماءه إلى الزمن الاستعماري مع ما يحمله ذلك من استلاب وتعبير عن غزو فكري يستهدف الهوية، ومَن يرى فيه جزءاً من حملة قديمة جديدة على منظومة القيم الإسلامية والهوية العربية بتمثّلاتما العقدية والفكرية والرمزية. فإذا كان الواقع التاريخي

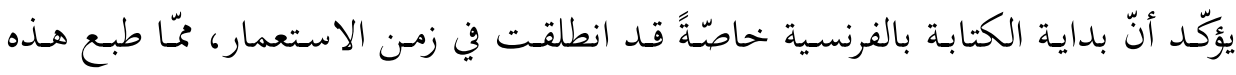
الإبداعات بنوع من التعبير الفرنكفوني المهمُّلّل لحماية لغوية وفكرية، فإنّ استمرارية هذا الصنف من الكتابة، وبلغة المستعمر، جعلها تعيش في إطار جدلية القبول والرفض، ميّا فرض عليها البحث الدائم عن شرعية الوجود وآليات التبرير. لذا، فقد عمد جُحلّ الكُّتّاب

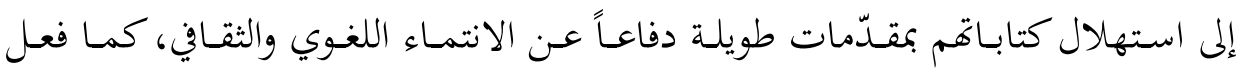
الطاهر بنجلون حين كال الحجج منافحاً عن وطنيته وإبداعه وانتمائه العربي، في الإجابة

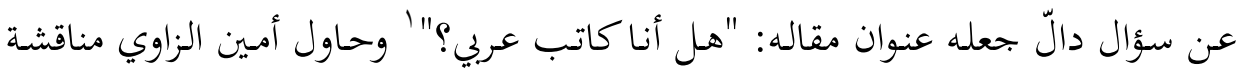

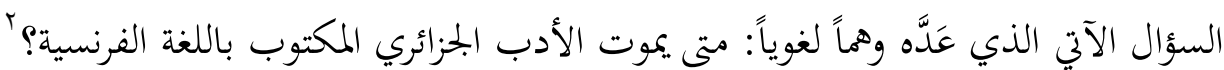

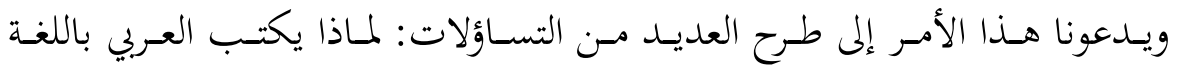
الفرنسية؟ ولمَنْ يكتب؟؟ وهل صارت الكتابة بلغة المستعمر جزءءً من إرث قديع، أو أهّا

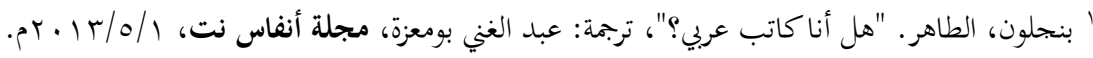

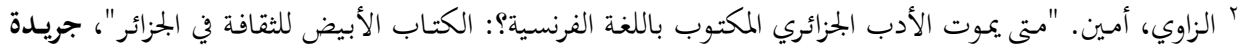

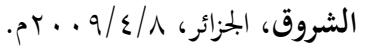




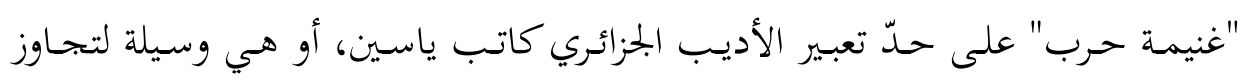

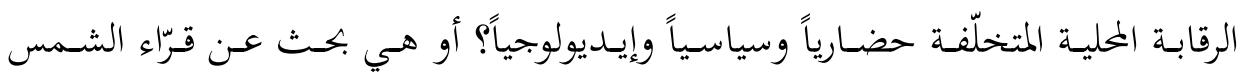

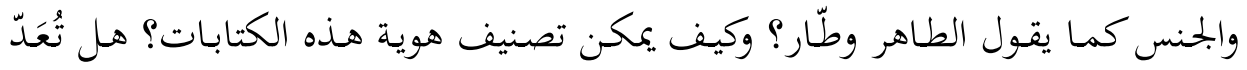

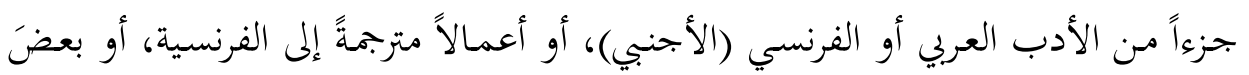

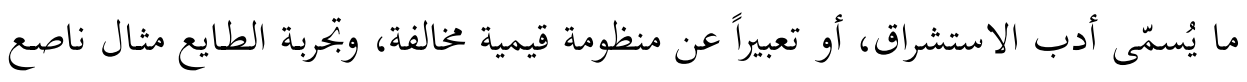

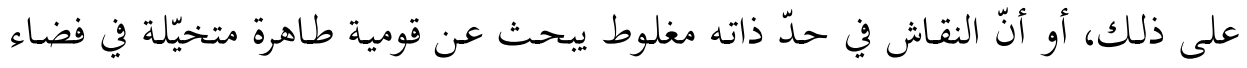

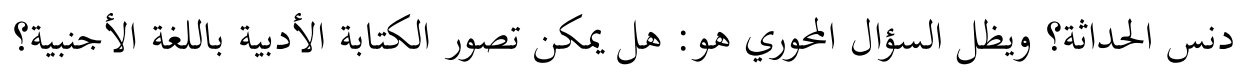
قد نسابق للقول بأنّا لسنا هنا في بجال محاكمة هذا الإبداع من القول، ولا القفز

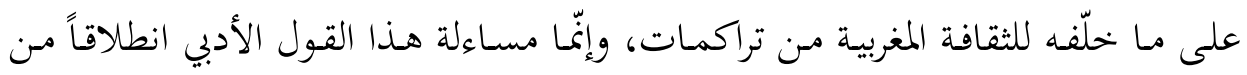

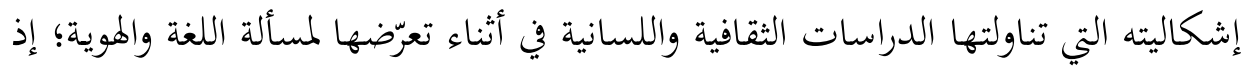

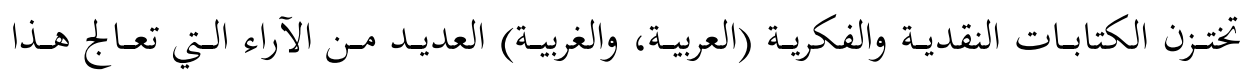
الصنف من الأدب، والتي يمكن تصنيفها إلى موقفين رئيسين:

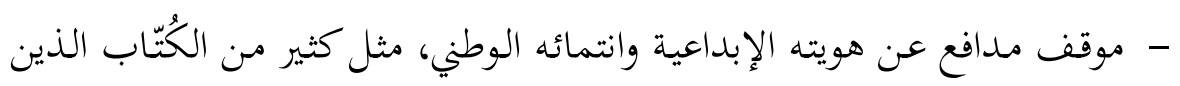

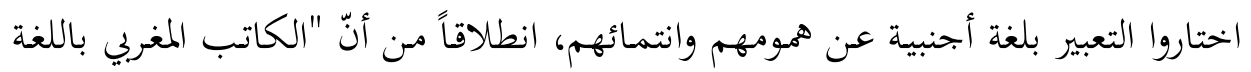

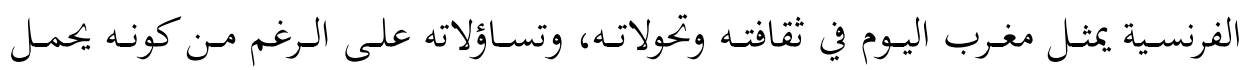

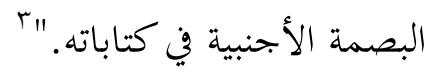

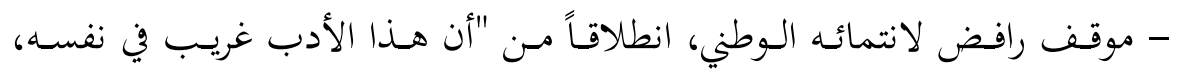
ومنفي عن موطنه الذي كتب فيه."

وقد دبج روّاد الموقفين -عموماً- بياناتٍ دفاعيةً أو هجوميةً، منافحةً أو منتقصةً من

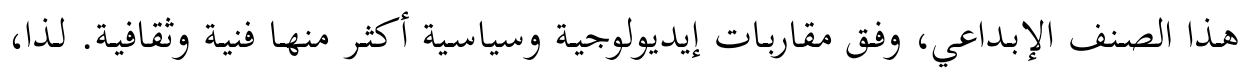

3 DEJEUX, J. Situation de la littératures Maghrébine de langue Française, Alger, Ed. OPU, 1982, p 216.

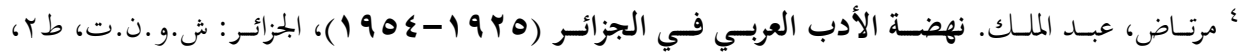

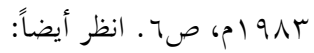

- حميش، بنسالم. الفرنكفونية ومأساة أدبنا الفرنسي، البيضاء: المعرفة للجميع، عددبآ، ص. - 11 . 
حاولنـا في هـذا البحــث أن نُقـدِّم رؤيـةً نقديـةً تعتمـد نظريـة القـراءة التراتبيـة التي تـداولتها الكتابات المابعدكولونيالية لفهم الظاهرة وطبيعتها بعيداً عن الرؤية الإيديولوجية الضيّقة، وتعسّف القراءة السياسية للكتابـة الإبداعية. فجعلنـا مـدار البحـث على مقدّمـة، وثلاثنة مباحـث، وخاتمـة. وقـــ اختصـ المبحــث الأول منهـا بضـبط دلالـة الهويـة وموقع الكائن اللغوي فيها، واهتم المبحث الثاني بتحديد موقع اللغة العربية في تكوين الهوية الوطنية كما تبلور في خطاب الهويـة، وتعرّض المبحـث الثالث لعلاقة اللغـة بالجنسية الأدبيـة ومعانـاة المبدع باللغة الأجنبية، وتناول المبحث الرابع قراءةً تراتبيةً للإبداع باللغة الفرنسية، في حين

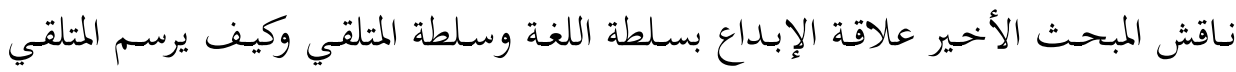

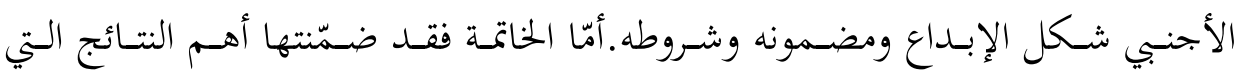
خرجت بها من هذه العناصر.

\section{أولاً: اللغة والهوية}

فرض مصطلح الهوية Identity نفسه بوصفه مفهوماً يحيل على العديد من الأبعاد

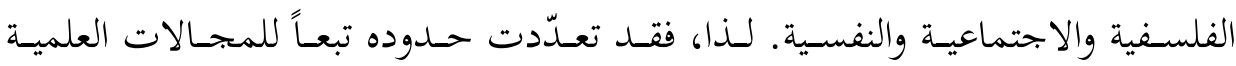

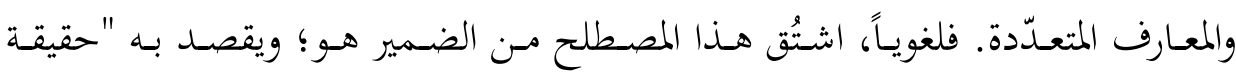
الشيء أو الشخص التي تميزه عن غيره." ولم يتوقّف أصحاب المعاجم عند هـا المعنى

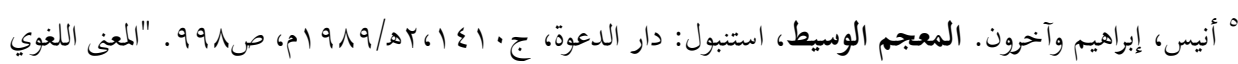

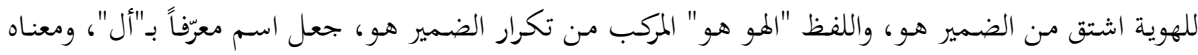

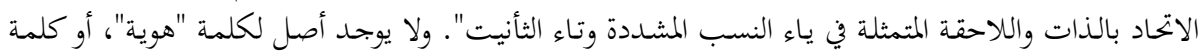

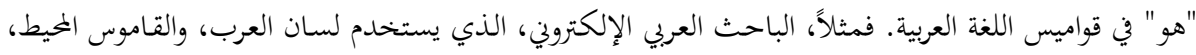

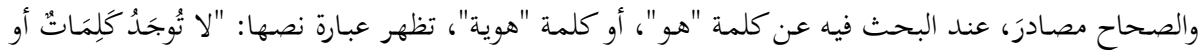

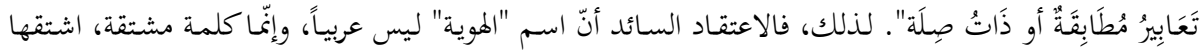

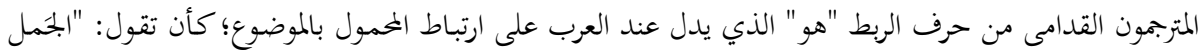

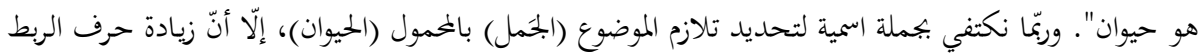

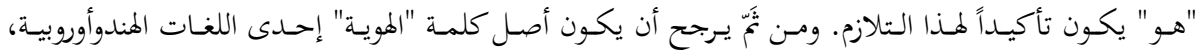

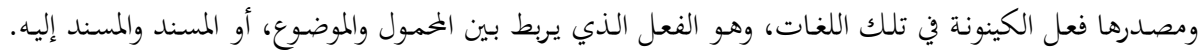

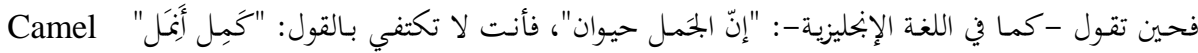


كثيراً، `لكنّه اتخذ في اصطلاحات الفنون معاني عدّة. `وهذا التعدّد في التوجيه الدلالي لا

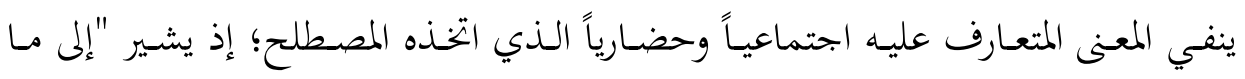

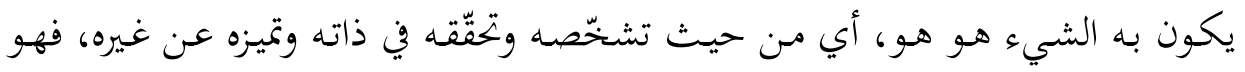
وعاء الضمير الجمعي لأي تكتل بشري، ومحتوى لهذا الضمير في نفس الآن، بمـا يشمله من قيم وعادات ومقومات تكيّف وعي الجماعة وإرادةًا في الوجود والحياة داخل نطاق

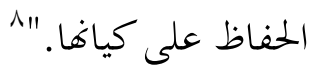

ويرى جهورج ميد أنّ الوعي بالذات ليس إنتاجاً فردياً صرفاً، وإنّما ينتج مـن بحموع

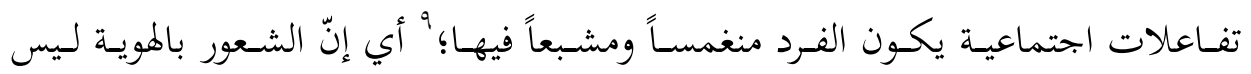

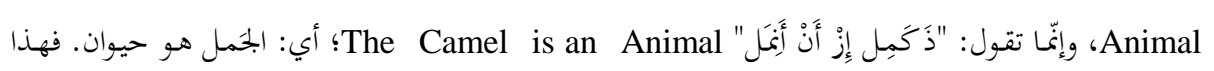

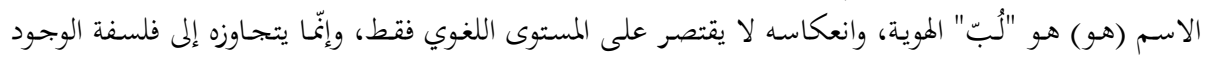

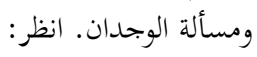

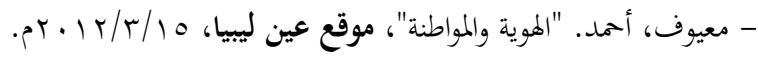

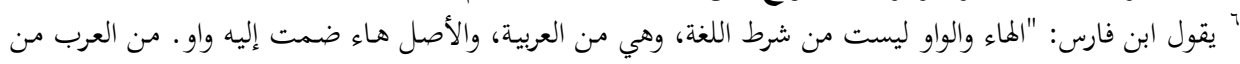

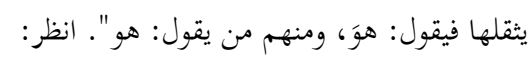

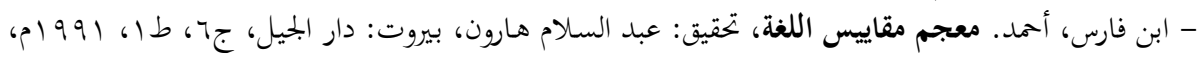
ص.

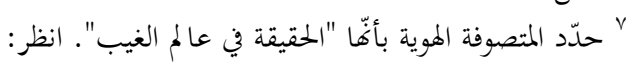

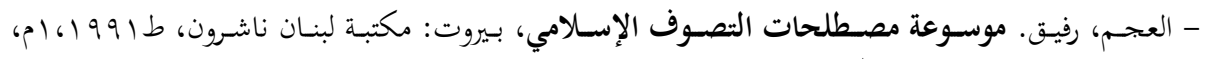

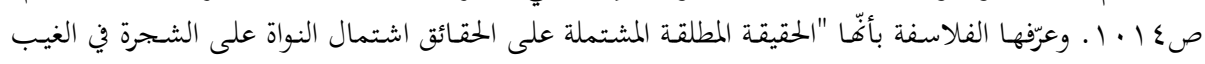

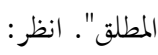

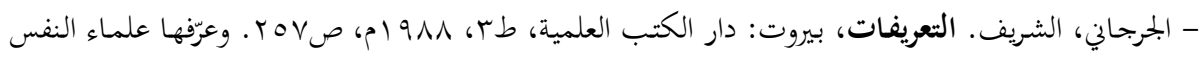

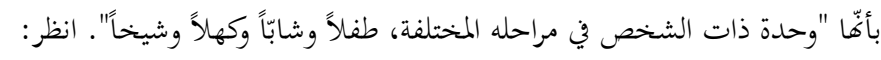

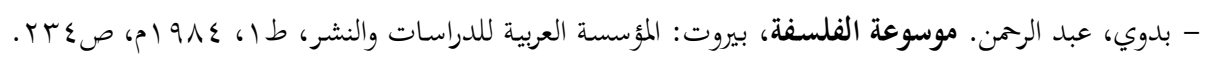

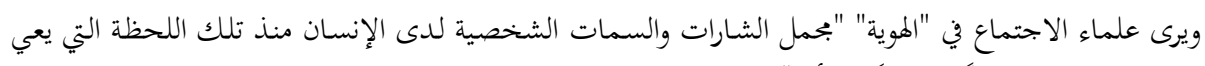

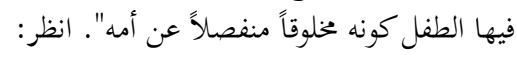

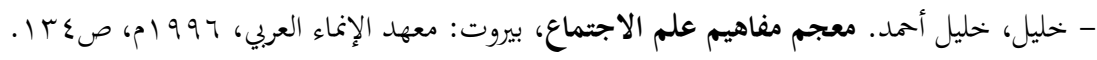

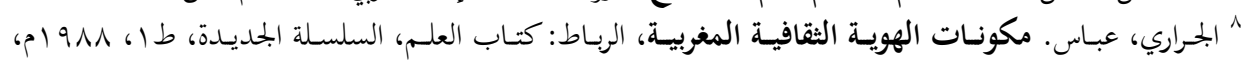
صזr. 9 نقلاً عن:

- لنيبانيانسكي، أدمون مارك. "كيف تتشكل هوية الجماعات؟"، ترجمة وإعداد: ماري شهرستان، مجلة تحولات،

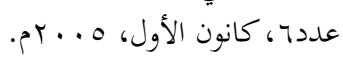




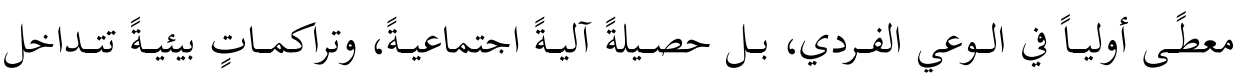

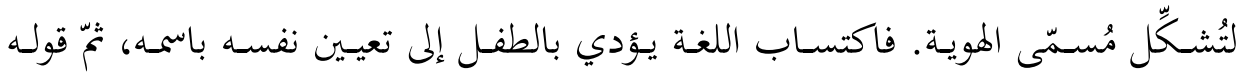

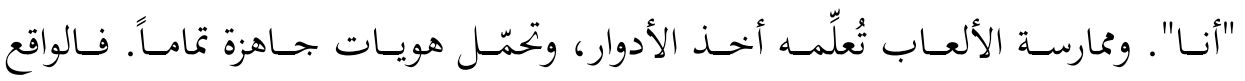

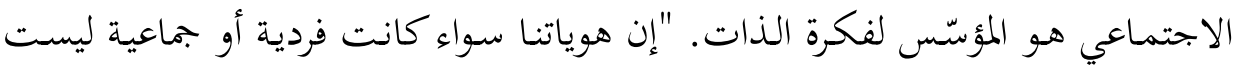

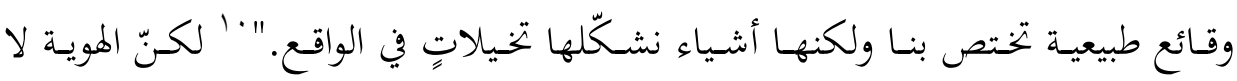

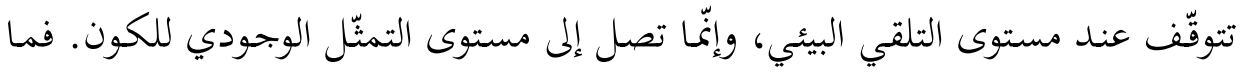

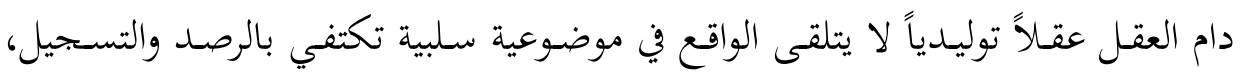

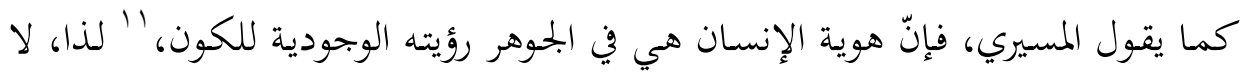

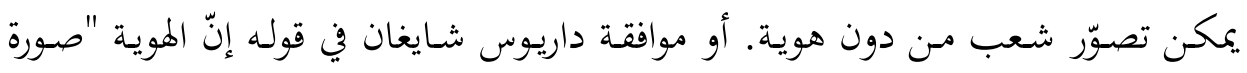

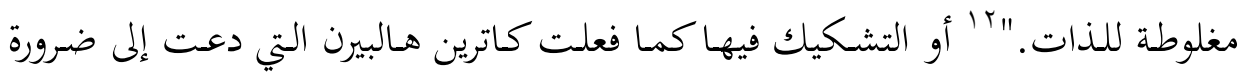

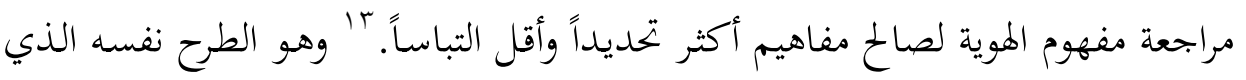

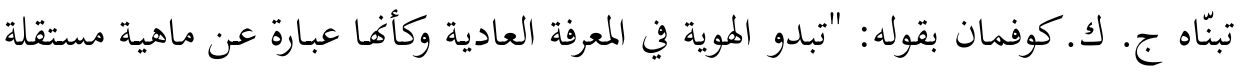

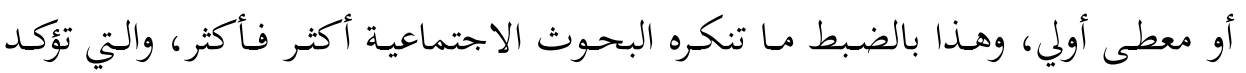

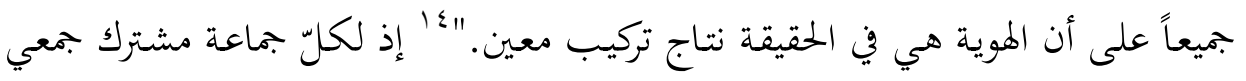

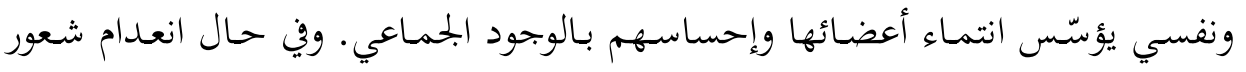

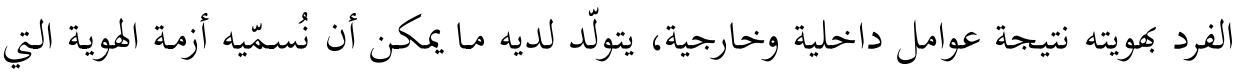

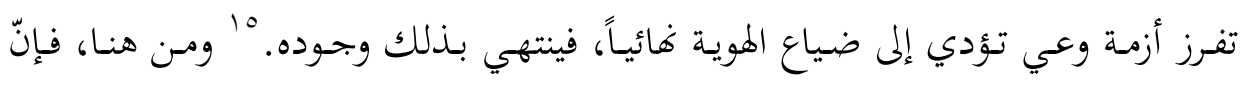

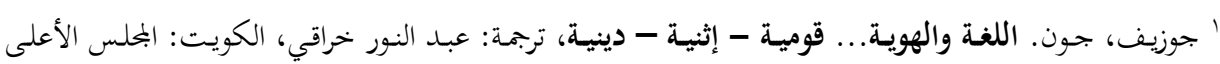

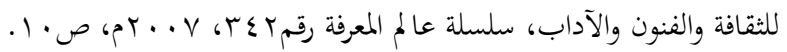

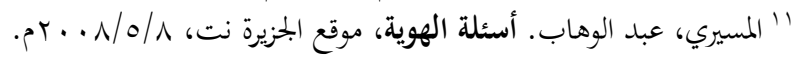

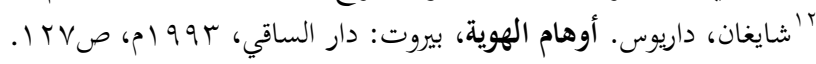

13 Catherine, Halpern. Faut-il en finir avec l'identité ?, scienceshumaines; 2004, no151,Auxerre, France, p 13;

${ }^{14}$ kaufman, jean claude. l'invention de soi- une théorie de l'identité, Paris, Armond colin,2004,cité par: Catherine Halpern, Faut-il en finir avec l'identité?, sciences humaines; 2004, no151,Auxerre, France,p.16.

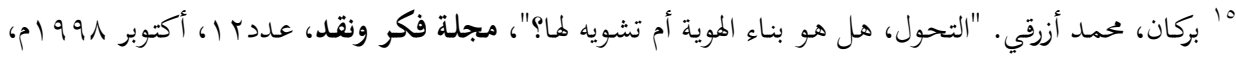




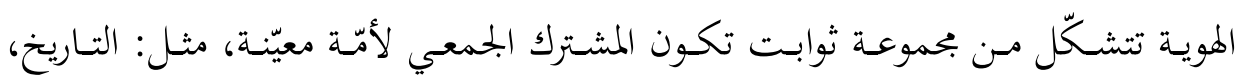

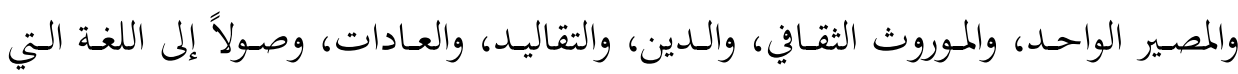

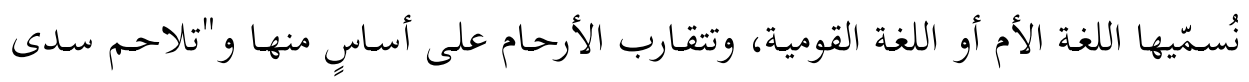

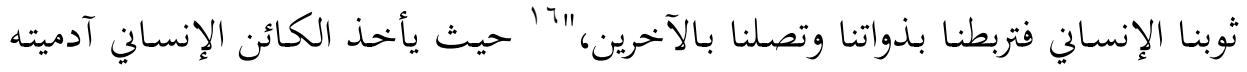

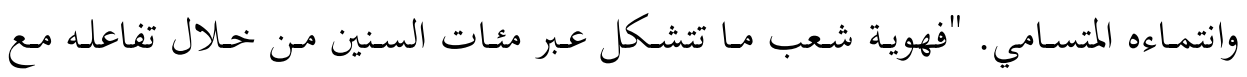

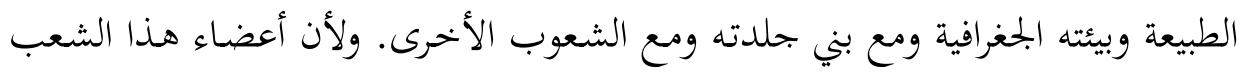

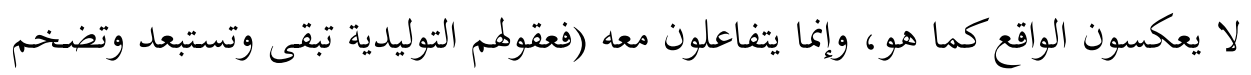

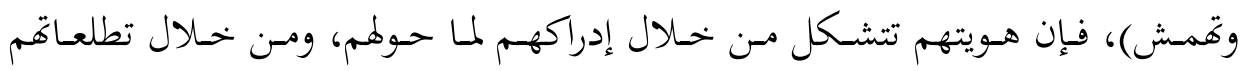

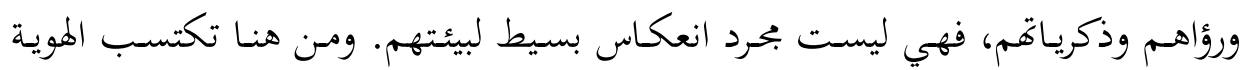

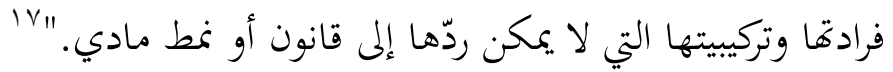

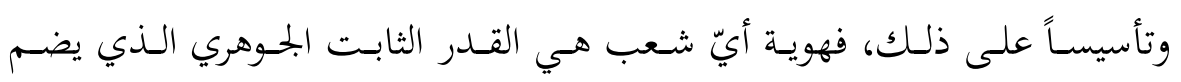

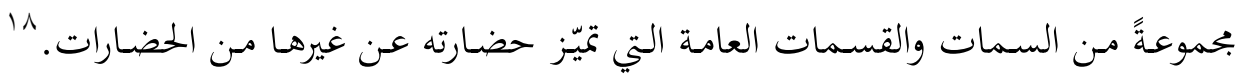

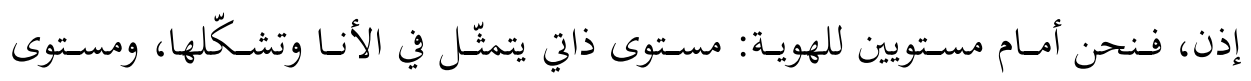

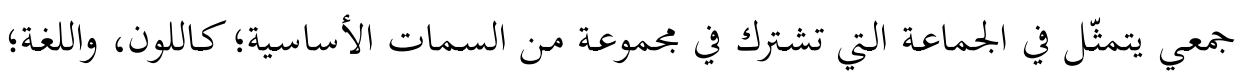
والسمات الوظيفية مثل الأدوار الاجتماعية.

وفي المقابل، تُعدّ الهوية انصهاراً بين عناصر المزايلة (المفارقة) وعناصر التماثل. فبتعبير

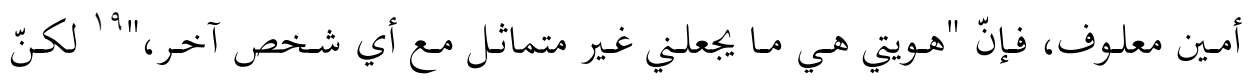

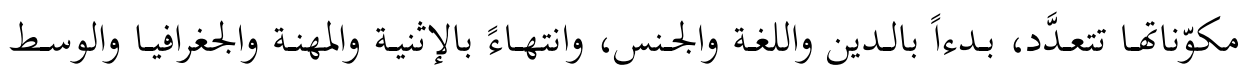

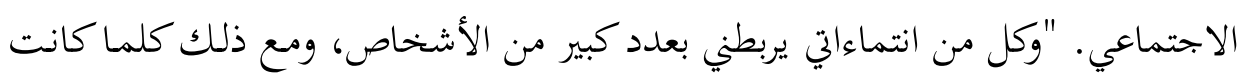

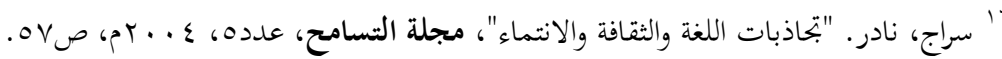

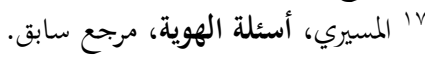

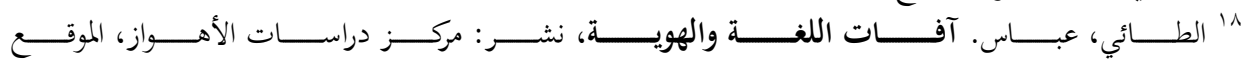

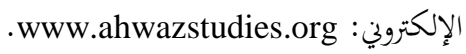

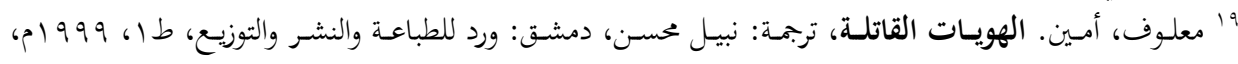




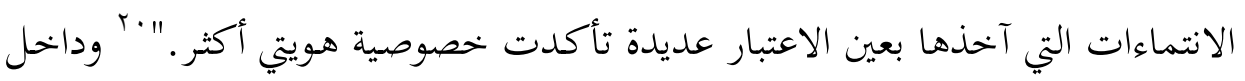

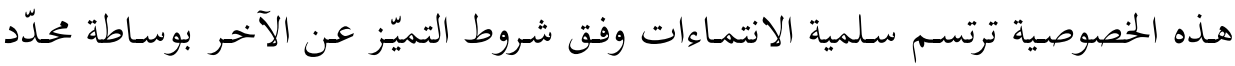

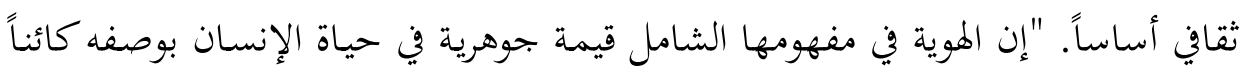

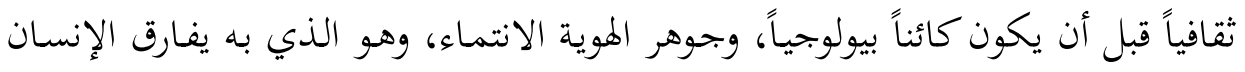

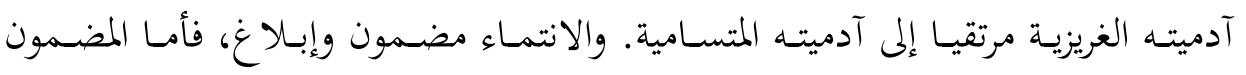

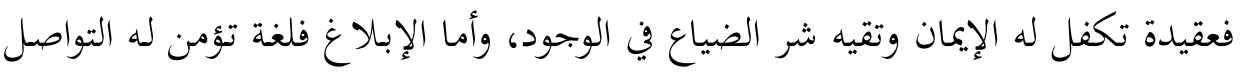

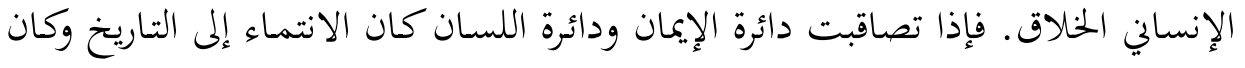

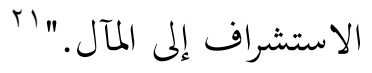

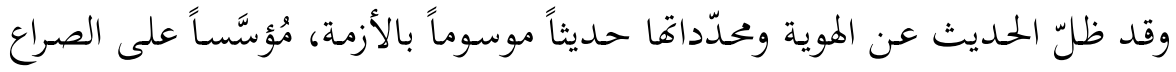

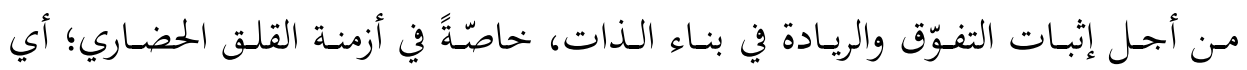

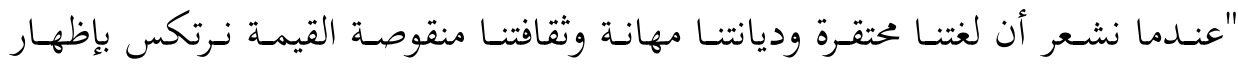

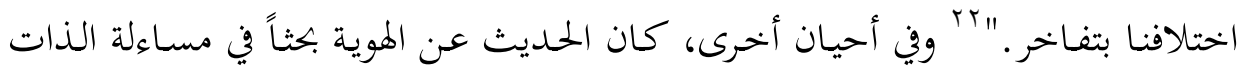

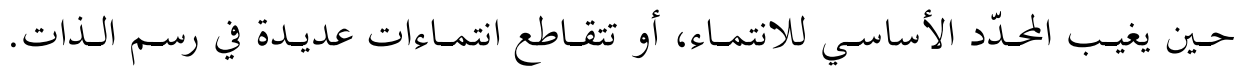

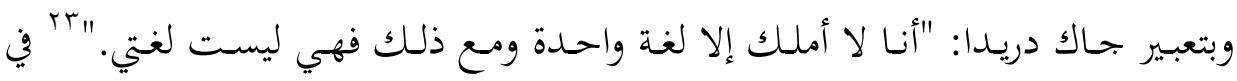

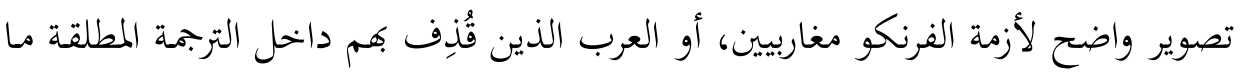

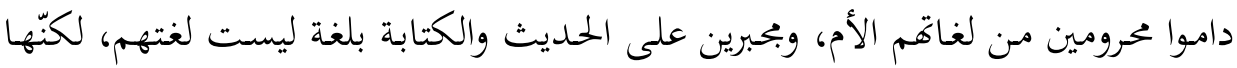

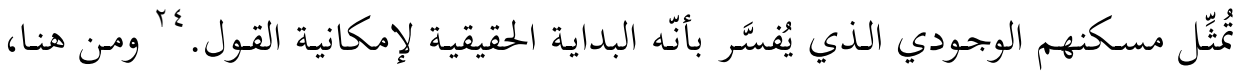

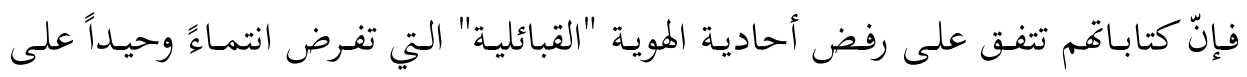

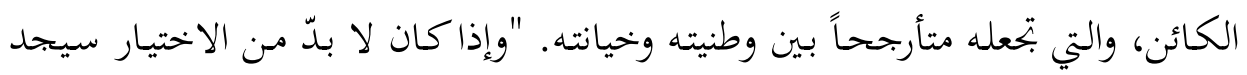

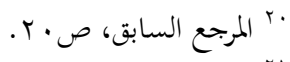

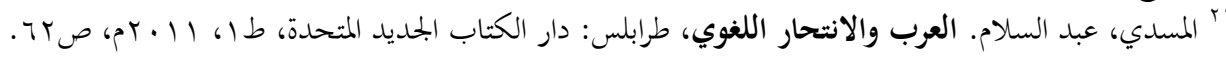

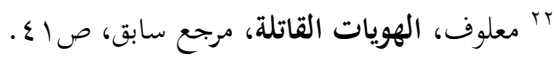

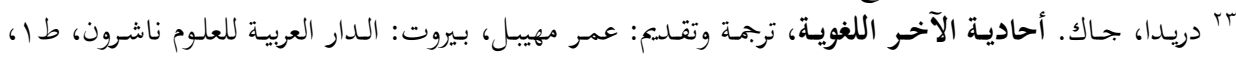

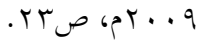

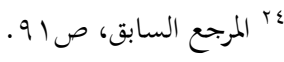


المهاجر أنه منقسم وممزق ومحكوم عليه بأن يخون إما وطنه الأصلي وإما الوطن المضيف

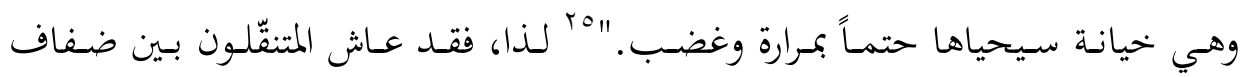

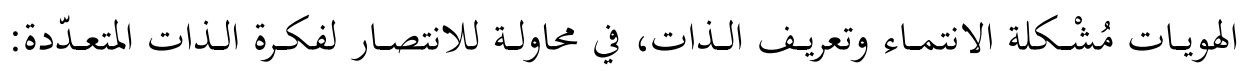
الهوية واحدة، ومكوّناقَا عديدة.

وإذا كانـت مكوّنات الهوية متعدّدة، فبإنّ للغة حضوراً قوياً حاسمـاً في رسـم معالمها وتخصيصها، قـد يفوق أحياناً السمُكوّن الديني؛ لأنّ "قدر الديانة أن تكـون حصرية أمـا اللغة فلا. يمكن أن نتحدث العبرية والعربية والإيطالية والسويدية في الوقت ذاته. ولكننا

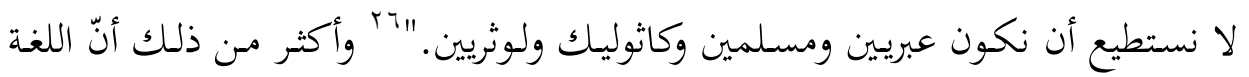
هي المحدّد الرئيس للهوية الثقافية للفرد والجماعة. "الرجل يستطيع أن يهيا دون أية ديانة

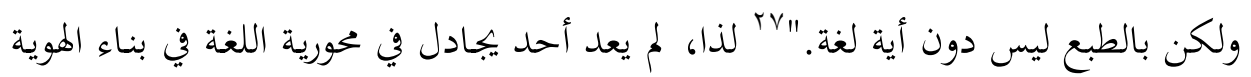

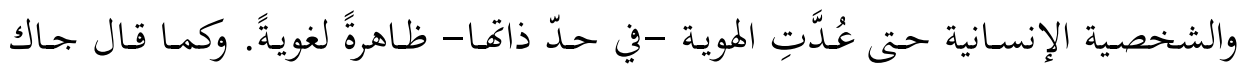
بيرك: "لا تصلح اللغة للتواصل، بل تصلح للوجود." "^^والكلام بلغة الجماعة يعني انتماءً

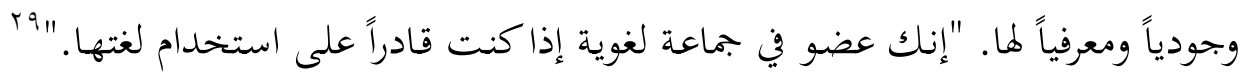

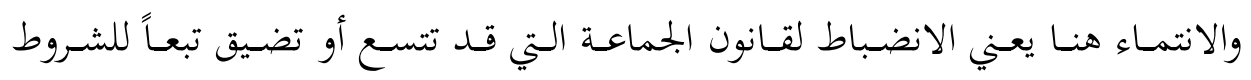
التاريخية والثقافية. فكانت اللغة هي القانون الأول الذي يفرض نفسه على كلّ فرد في أثنـاء عمليـة التنشـــة الاجتماعيـة الـتي تقــوده إلى الانتقــال "مــن الطبيعـة إلى الثقافـة".

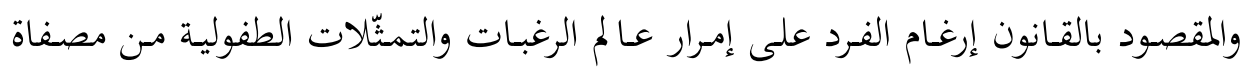

$$
\begin{aligned}
& \text { ror معلوف، الهويات القاتلة، مرجع سابق، صrVI. }
\end{aligned}
$$

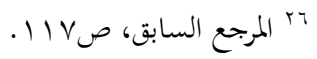

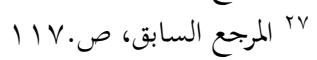

ץ^ Réflexion du professeur Jacques Berque, lors des Entretiens interdisciplinaires organisés au Collège de France sur le thème de l'arabisation en mai 1977. cité par Guillaume,Gilbert, Langue, Identité et culture nationale au Maghreb, Peuples Mediterranean, N9, oct-dec 1979, p.3

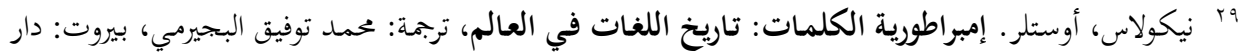

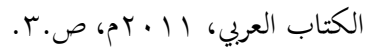




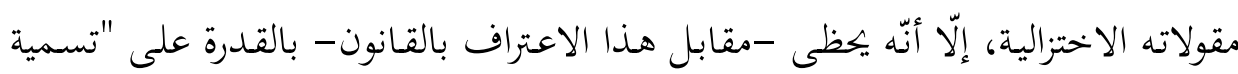

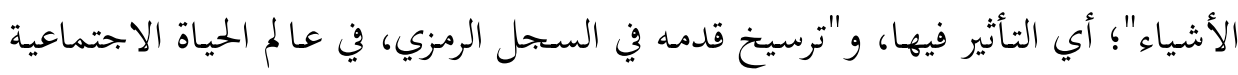

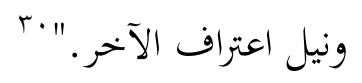

وقد انتقلت اللغة -مع القومية الأوروبية خاصِّةَ- إلى صناعة هويات قومية بناءً على فئل

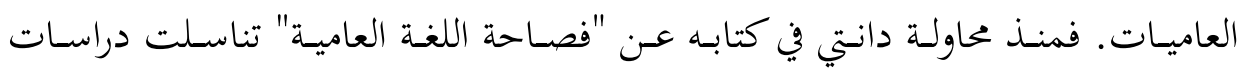

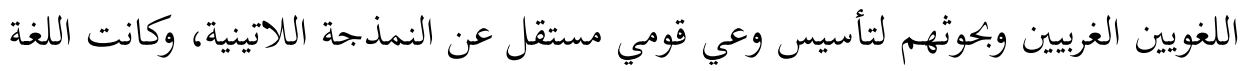

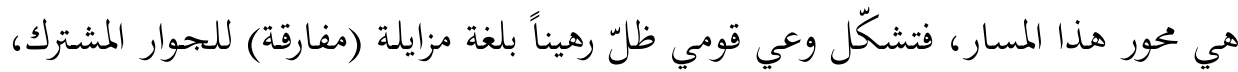

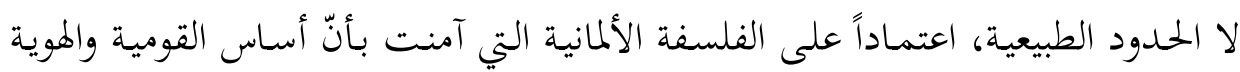

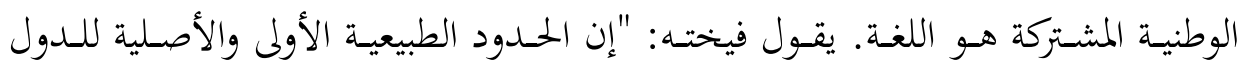

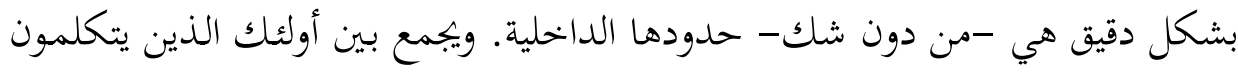

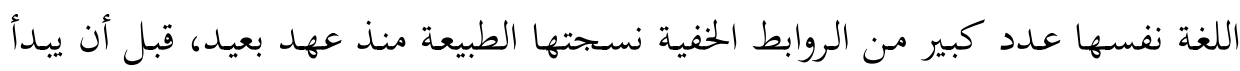

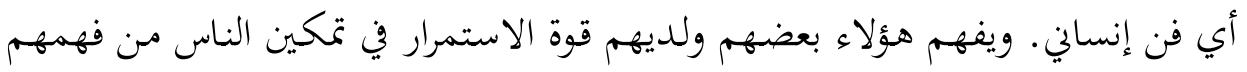

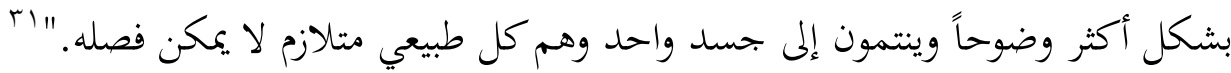

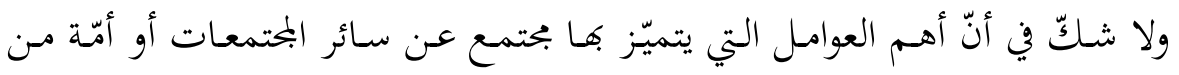

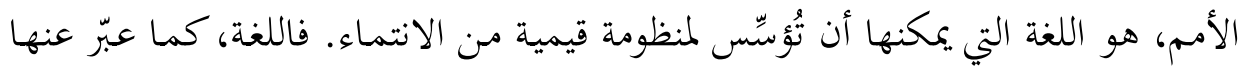

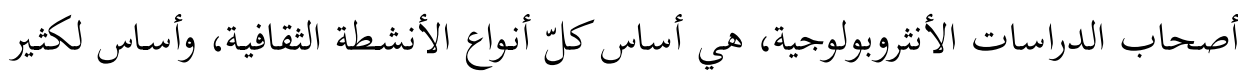

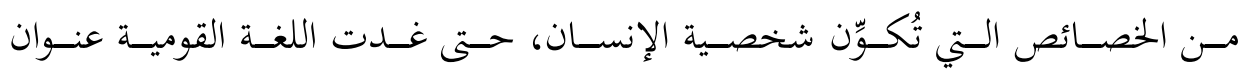

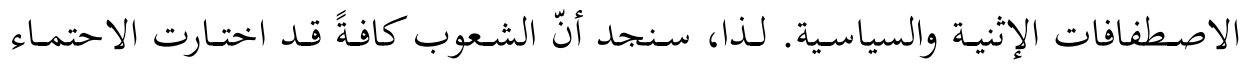

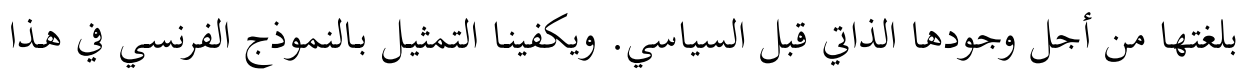

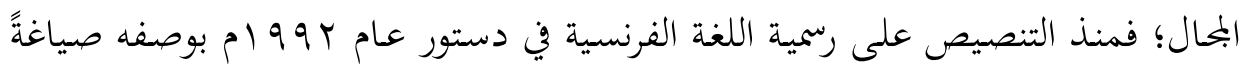

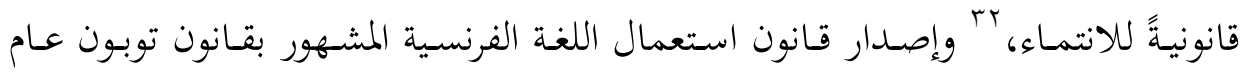

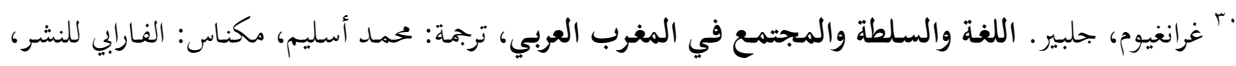
(1990 199

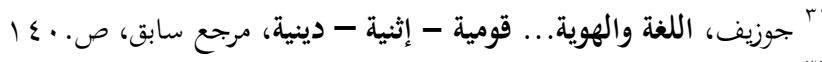
rr آنظر: الفصل الثاني من دستور الجمهورية الفرنسية، موقع البجلس الدستوري الفرنسي الإلكتووني: 
ع 99 ام (نسبةً إلى وزير الثقافة) الذي قام على ثلاث غايات رئيسة، هي: إغناء اللغة الفرنسية، ولزوم استعمالها، والدفاع عنها بوصفها لغة الجمهورية؛ عُدَّتِ اللغة القومية شأناً

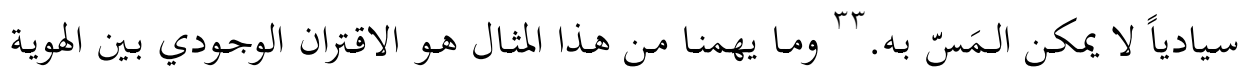

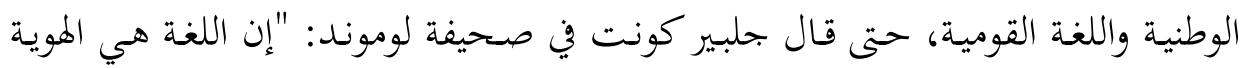

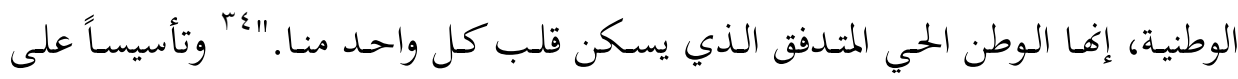
ذلك، كانت اللغـة -ومـا تزال - عنوان وجود الأمّة، ومرتسمهـا جوهر الأسـاس ومظهـر

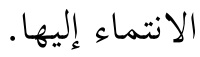

\section{ثانياً: اللغة العربية والهوية الوطنية المغربية}

في ما يخصّ الحالة المغربية، فقد ارتبط الحديث عن العلاقة بين اللغة والهوية بأدبيات الحركة الوطنية التي نظرت إلى الدولة القطرية، وربطت البُعْد اللغوي العربي بالمزايلة عن الثقافة والتعليم الاستعماري. "والجمدير بالذكر في هذا السياق أن مصطلح الهوية لم يكن متداولاً في الحياة الفكرية والثقافية في مطالع هذا القرن، فلم تكن الهوية من ألفاظ الثقافة

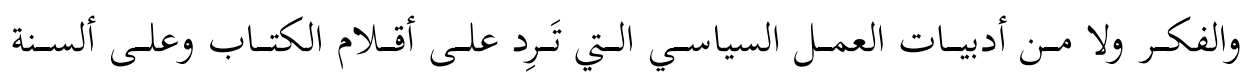

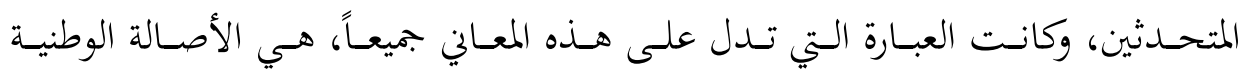
والشخصية الوطنيـة بـل إن مفهوم الحركة الوطنيـة نفسه كـان ينطوي على هـذه المعـاني،

- http://www.conseil-constitutionnel.fr/

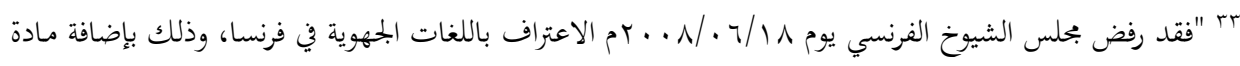

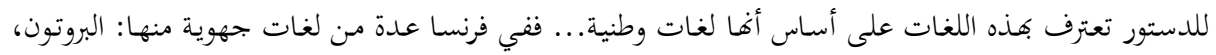

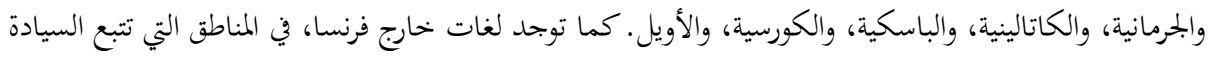

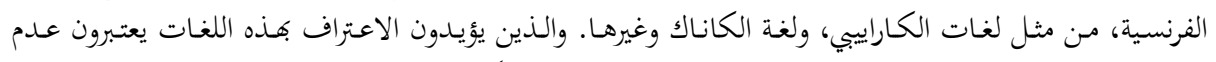

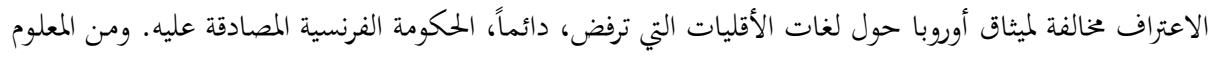

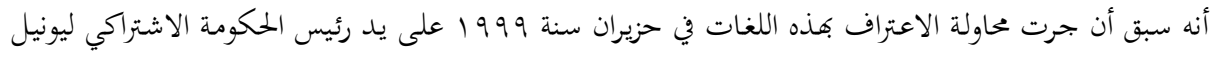

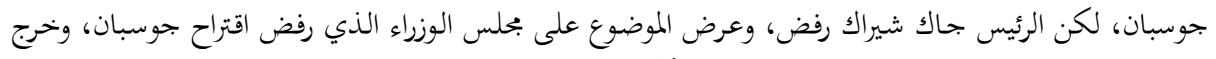

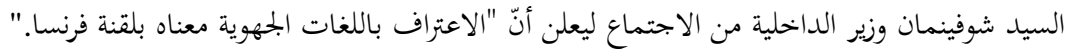

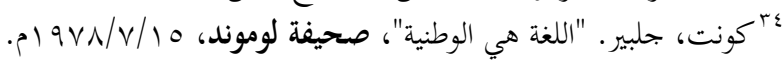




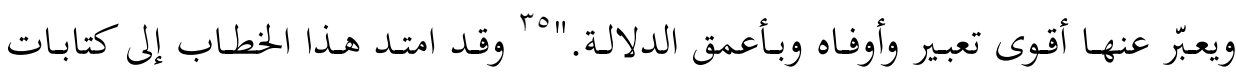

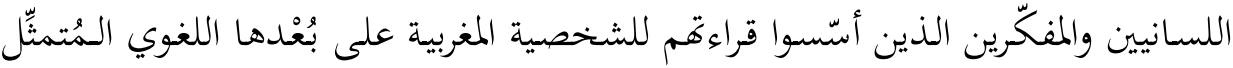

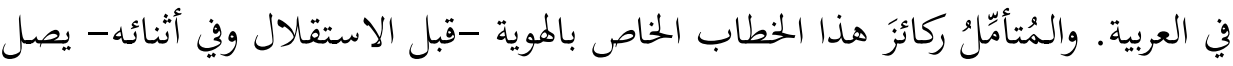
إلى جملة من العناصر التأسيسية التي أطرّته: ا ـ ارتبـاط العربيـة بالهويـة الوطنيـة المغربيـة: إذا كانـت اللغـة جـزءاً مـن الهويـة

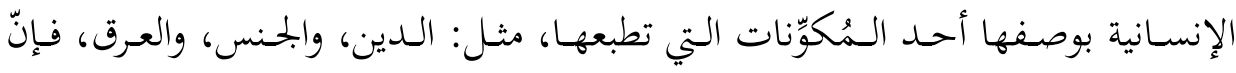

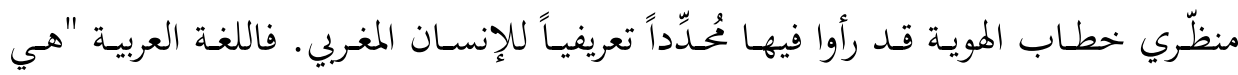

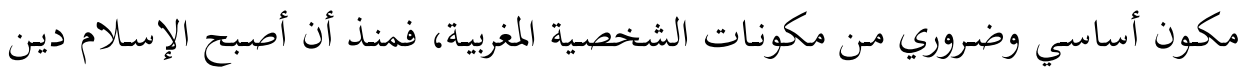

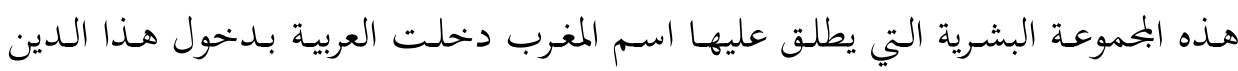

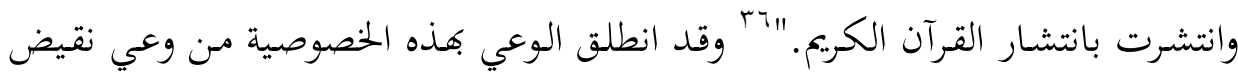

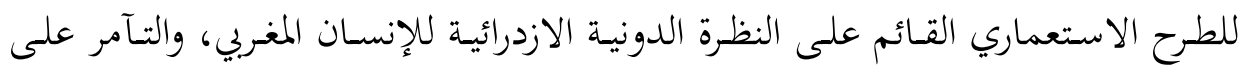

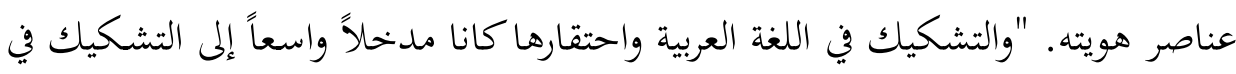

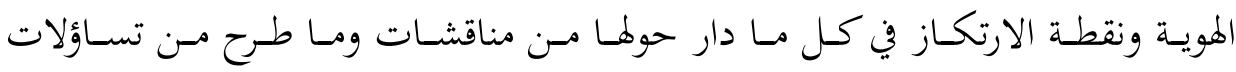

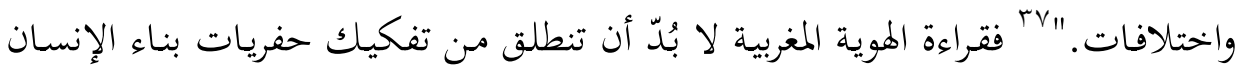

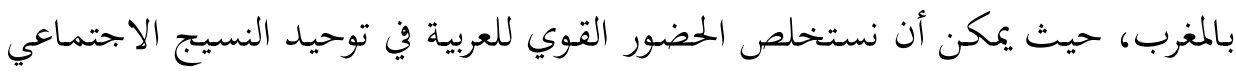

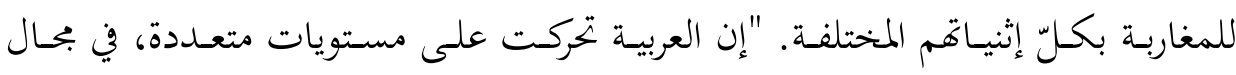

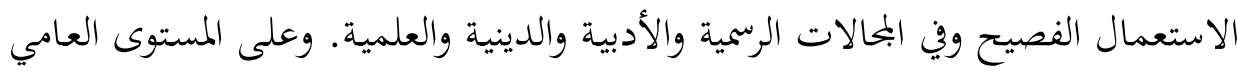

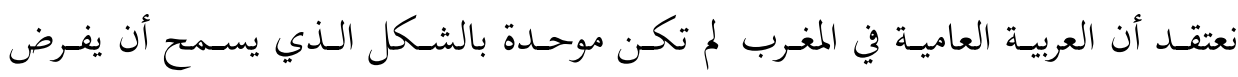

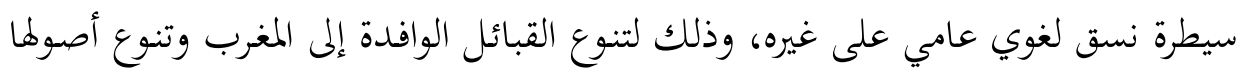

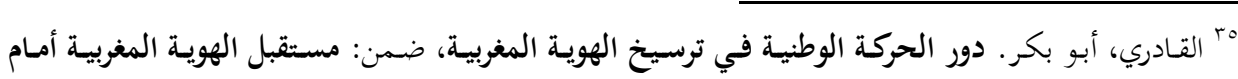

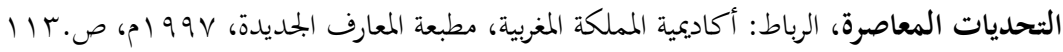

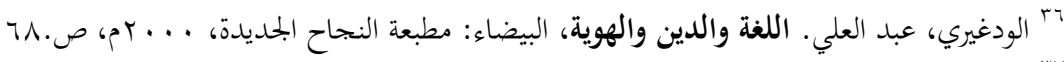

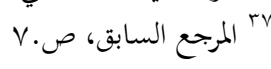




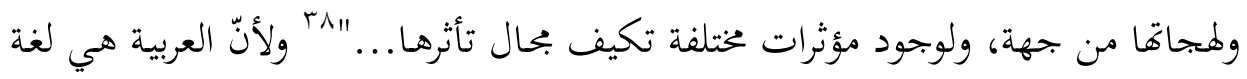
التماسك الاجتماعي، ج" فإنّ وجودها القانوبي ضروري للحفـاظ على اللحمة الاجتماعية

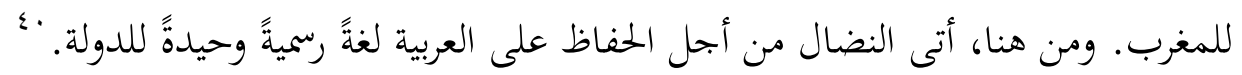
r. اندراج العربية في سياسة الإصـاح التعليمي: لا يفتأ خطاب الهوية يؤكّد أنّ

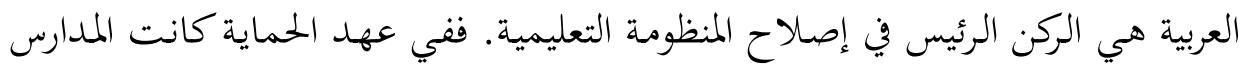

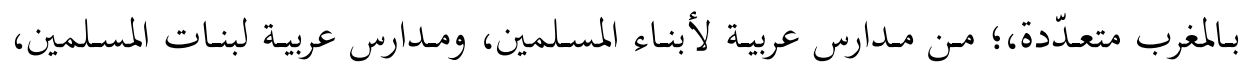

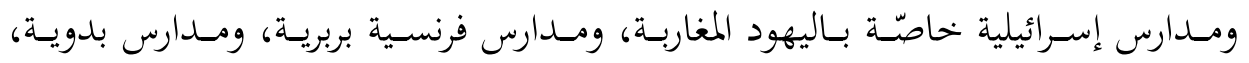

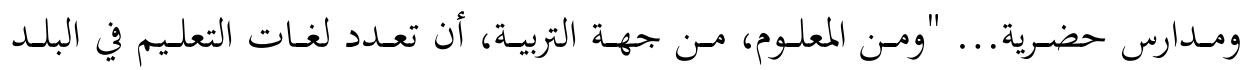
الواحد يضر أضراراً فاحشة بتكوين الأبناء ومستقبل الثقافة في الوطن، وإن واجب إنب الدولة

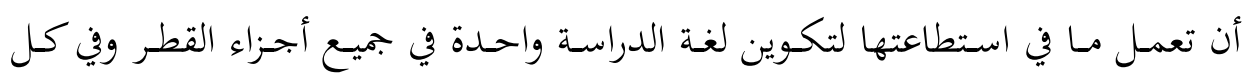

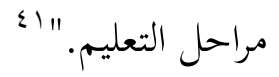

ولا شـكّ في أنّ هـذا التعدّد التربوي سينعكس علمى الهويـة الثقافيـة للذات الوطنيـة،

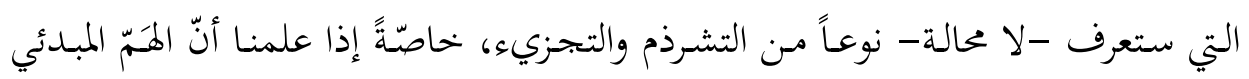

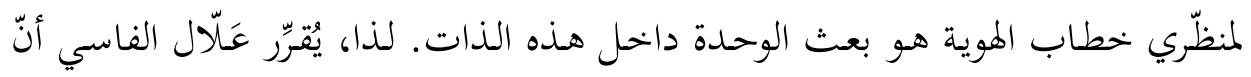

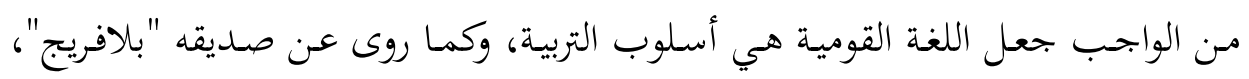

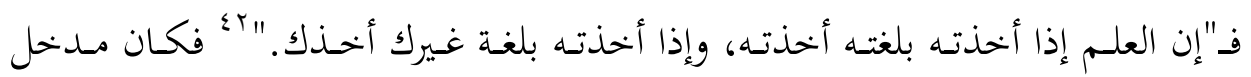

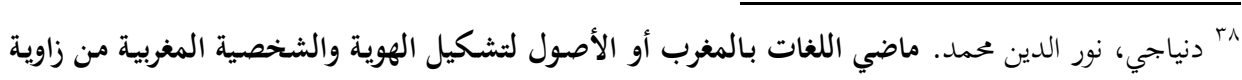

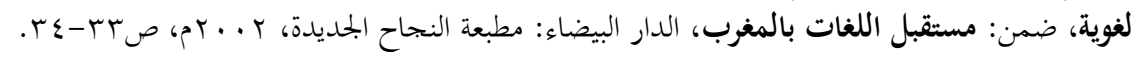

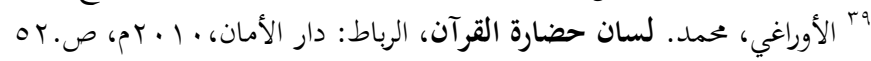

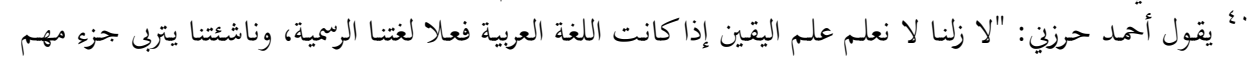

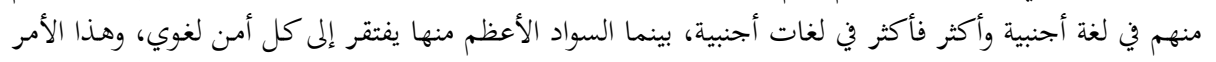

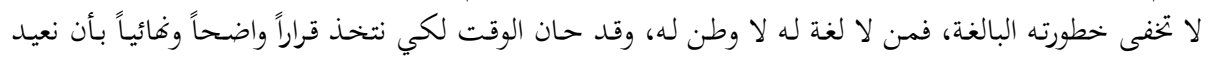

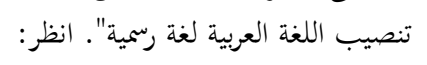

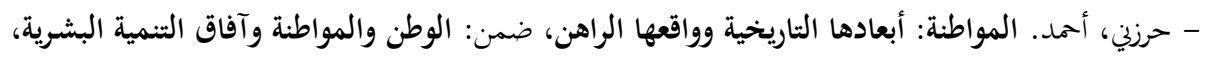

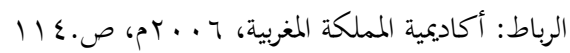

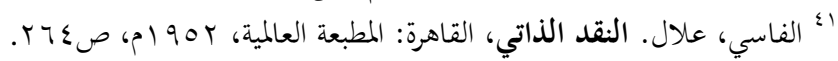

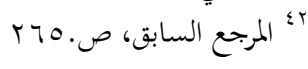




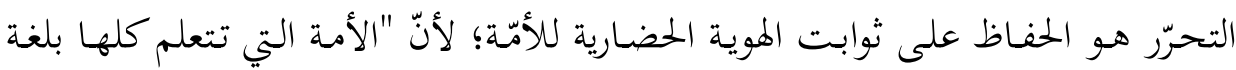

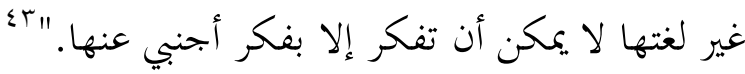

إنّ هـا التعدّد في لغات التدريس معناه فتح المحال للتفكير بطرائق عدّة، وترسيخ

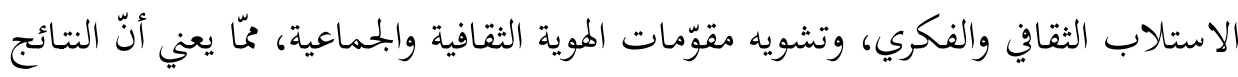

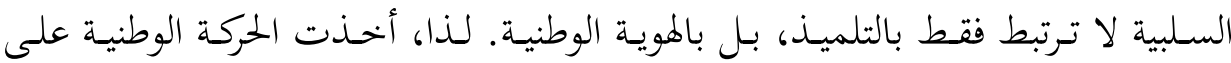

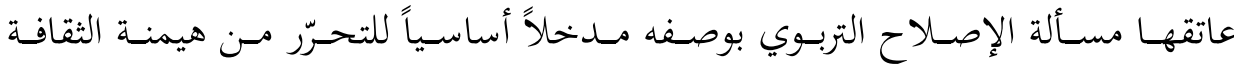

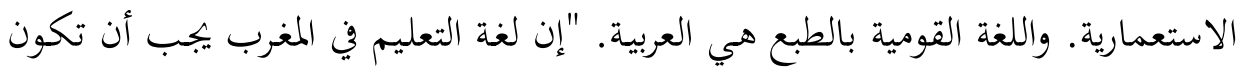

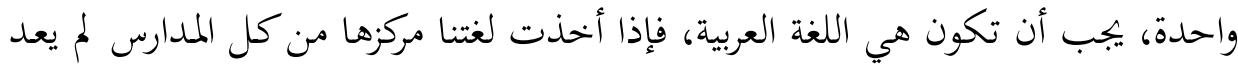

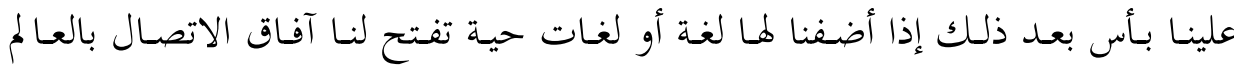

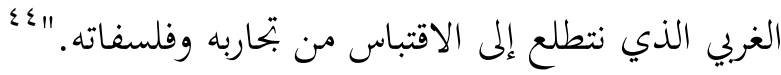

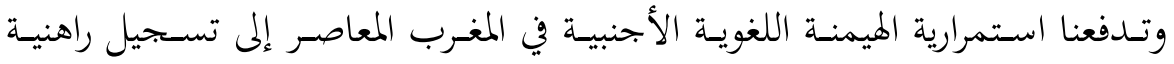

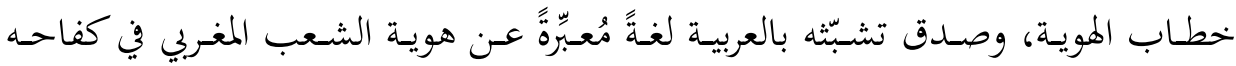

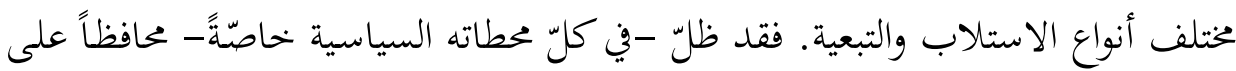

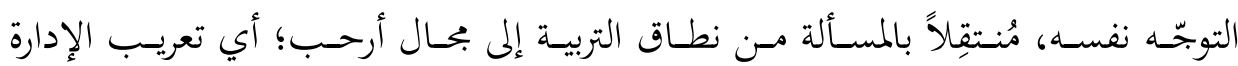

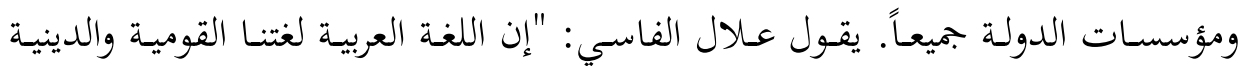

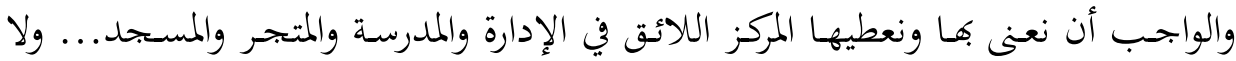

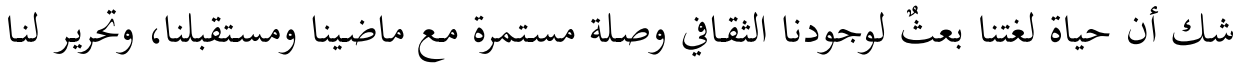

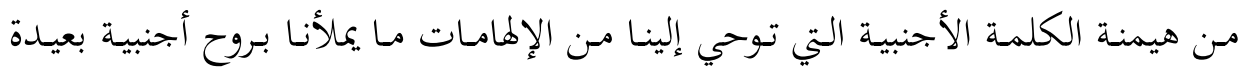
عنا."

ب. الانتمـاء العقدي إلى العربيـة: لا شــُّ في أنّ أهـم مـداخل التقديم الاعتبـاري

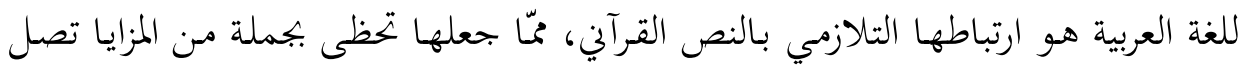

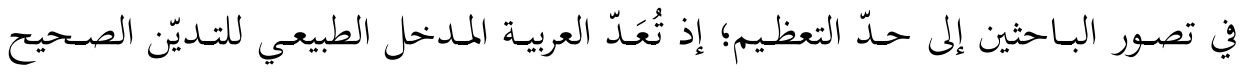

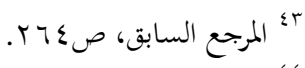

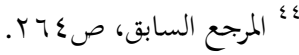

$$
\begin{aligned}
& \text { ه؛ المربع السابق، صغ صغ صب. }
\end{aligned}
$$




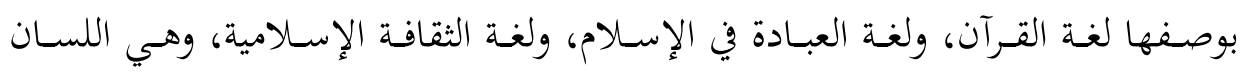

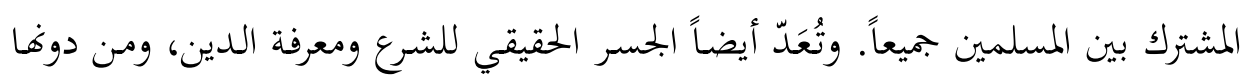

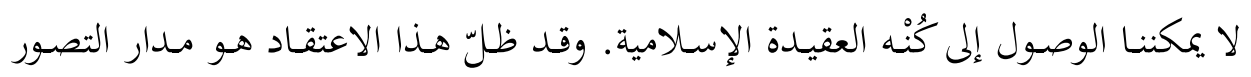

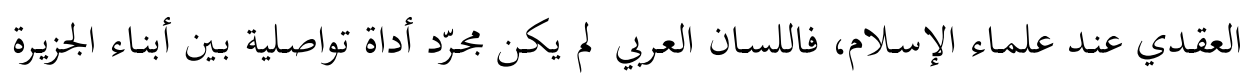

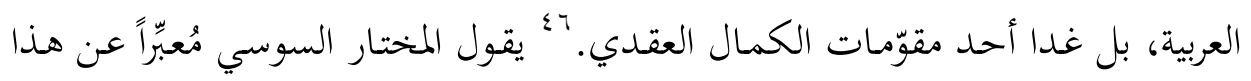

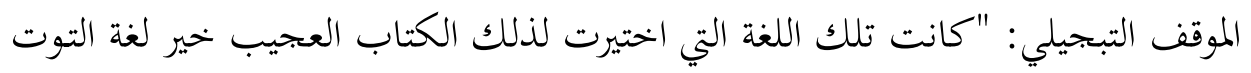

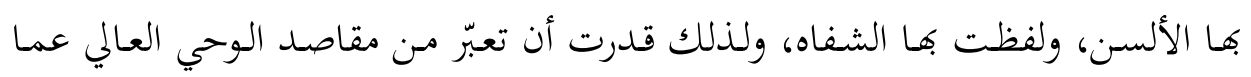

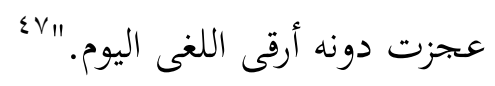

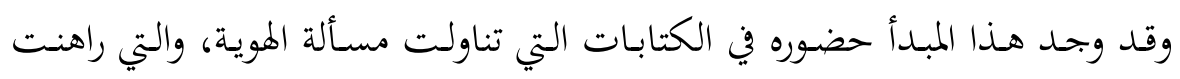

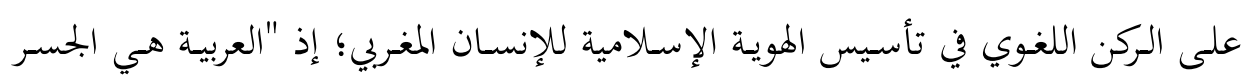

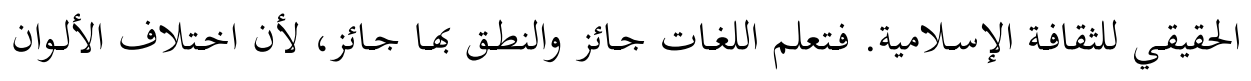

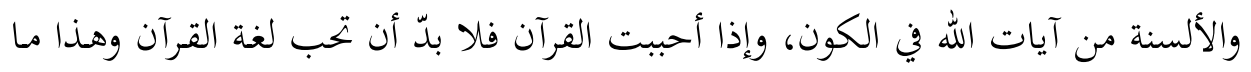

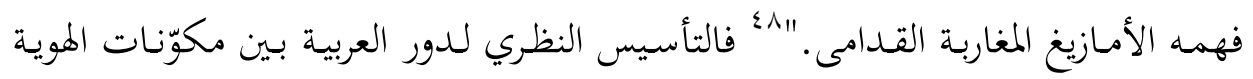

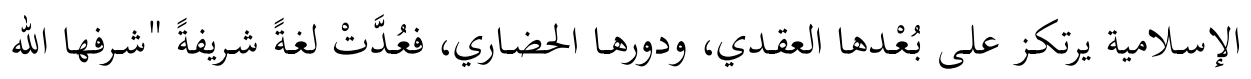

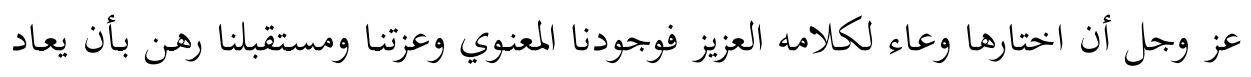

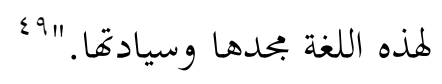

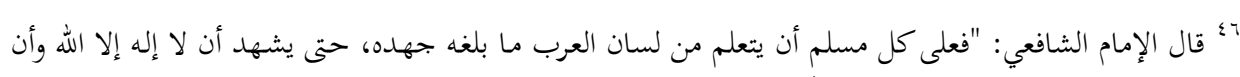

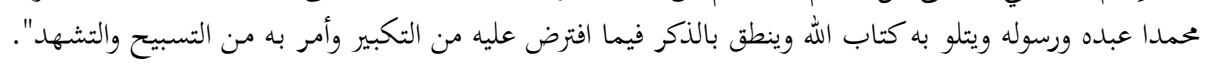
انظر:

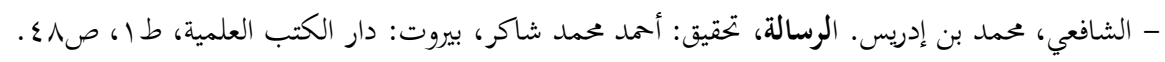

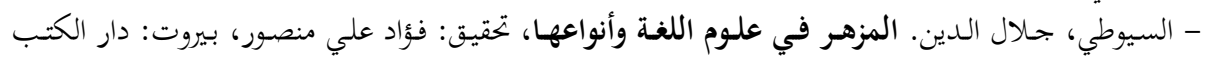

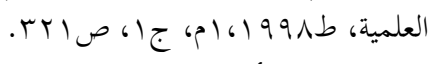

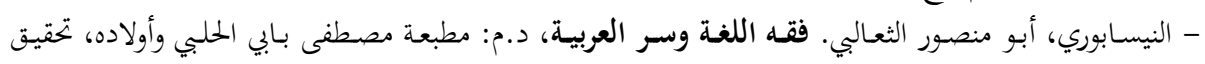

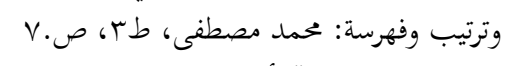

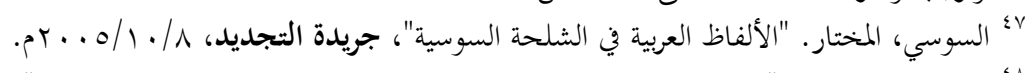

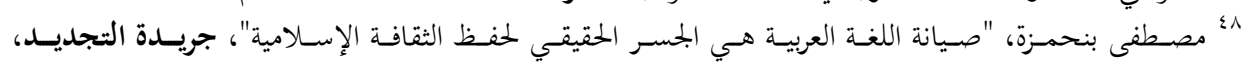

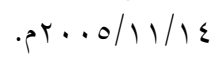

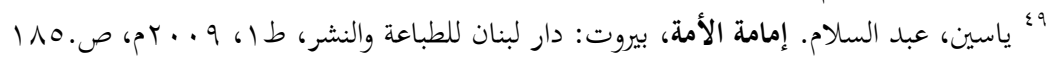




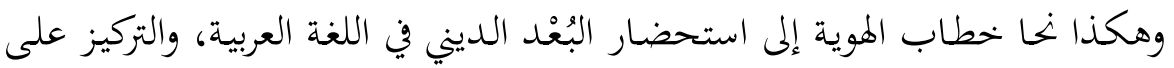

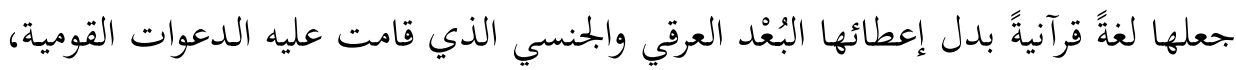

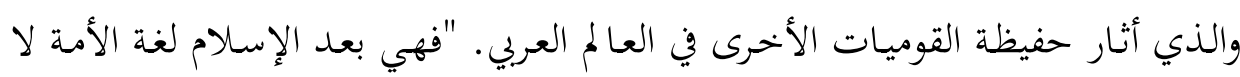

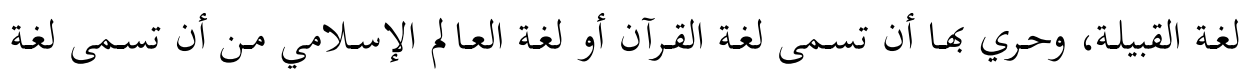

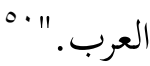

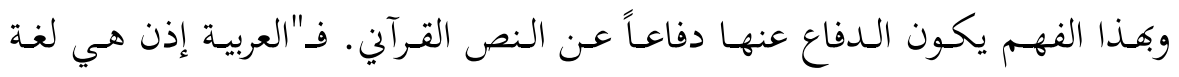

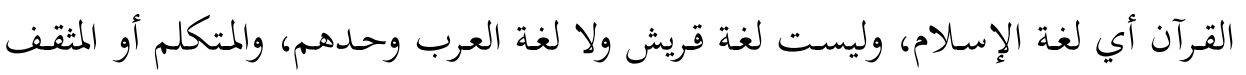

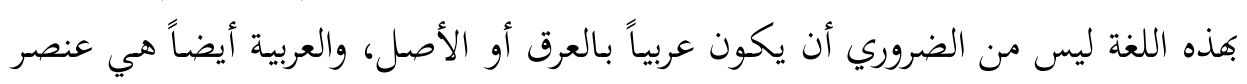

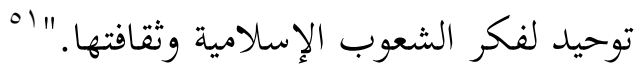

لقد ظلّ خطاب الهوية -منذ تأسيسه على يد روّاد الحركة الوطنية، وتبلوره في أدبيات

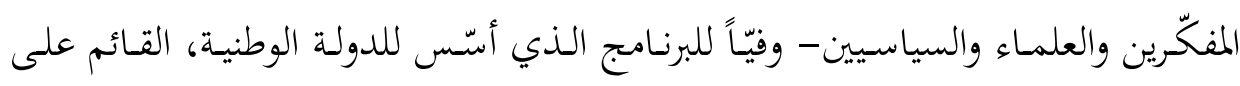

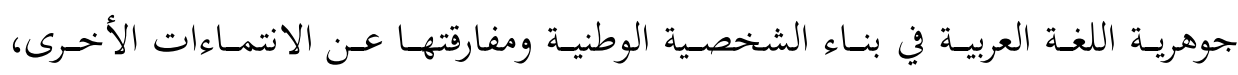

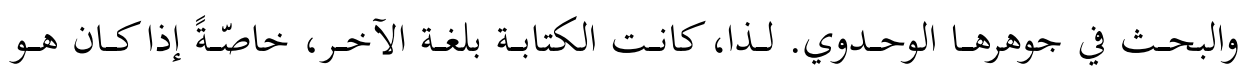
المستعمر، أحد بتلّيات الزمن الكولونياتي.

\section{ثالثاً: الأدب المكتوب باللغة الأجنبية والهوية المخدوشة}

قد لا نختاج إلى سردٍ للنصوص المنافحة عن الهوية العربية للأدب المكتوب باللغة

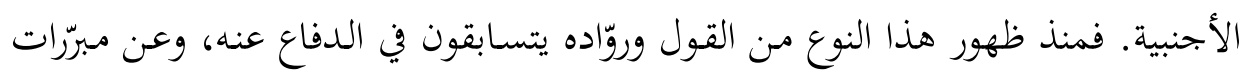

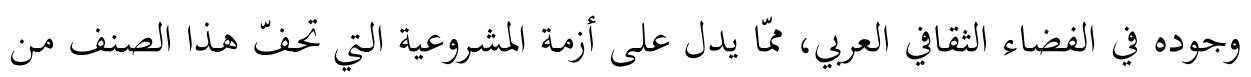

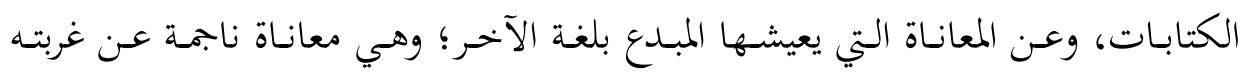

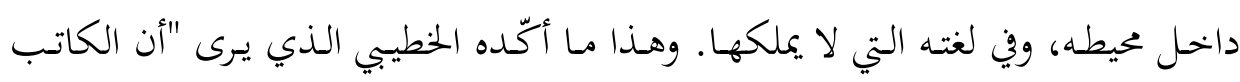

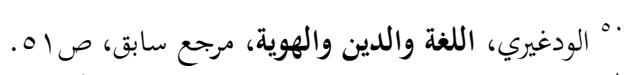

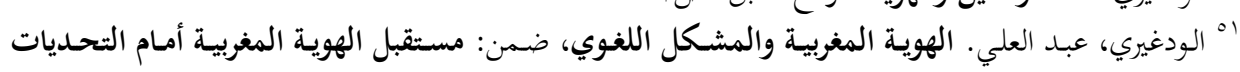

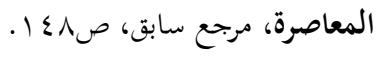


العربي باللسـان الفرنسي محجوز عليه داخحل عبـارة محددة عبـارة متأرجحة بـين الاغتراب

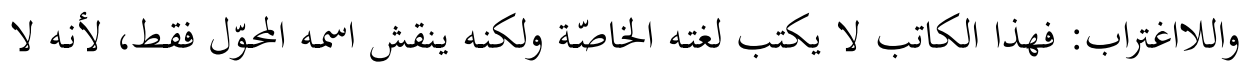

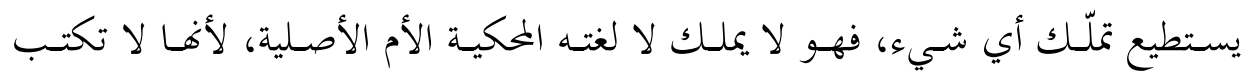

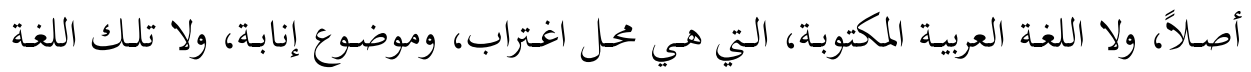

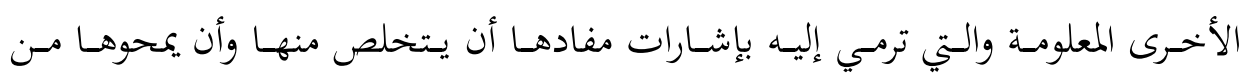

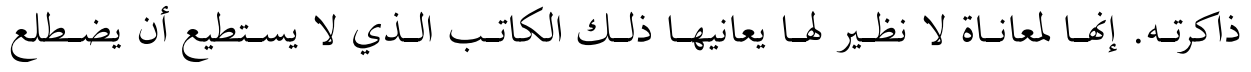

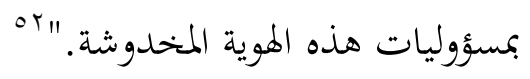

وفي المقال الموسوم بـ"هل أنا كاتب عربي؟يبحث الطاهر بنجلون في العلاقة القائمة

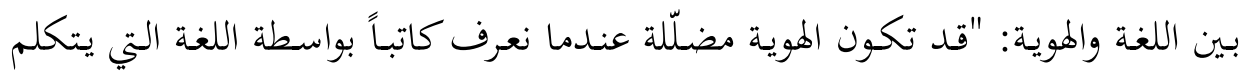

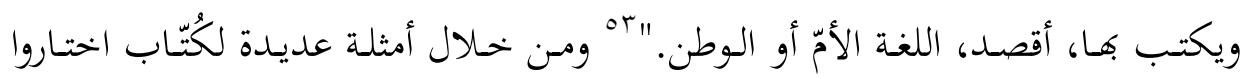

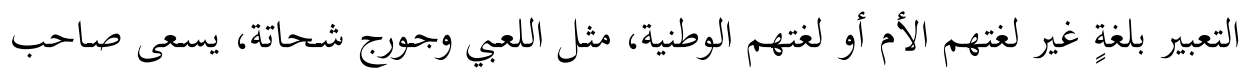

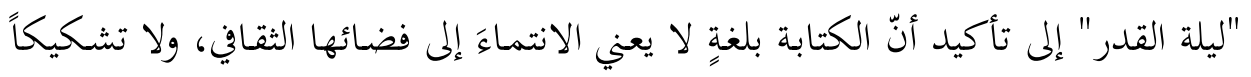

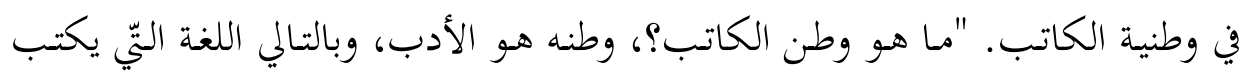

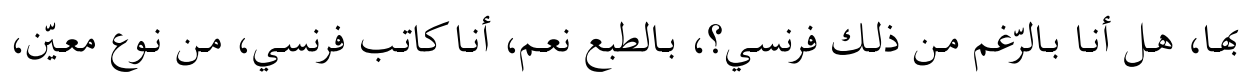

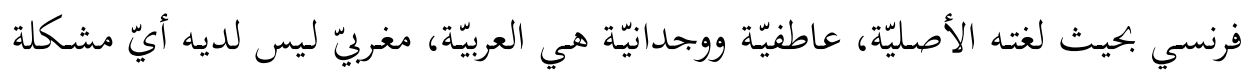

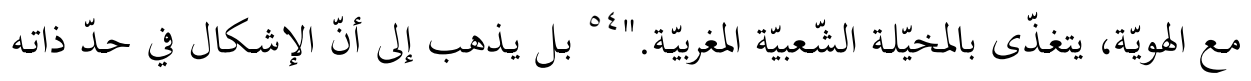

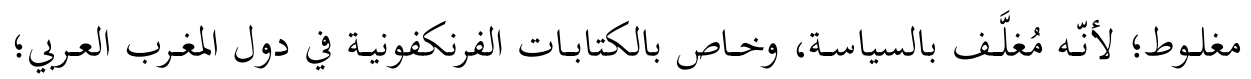

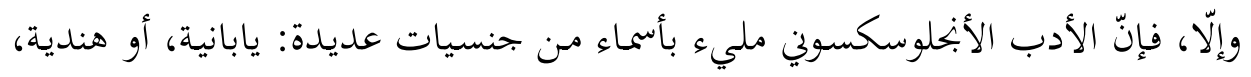

${ }^{52}$ Khatibi, Abdelkébir. Du bilinguisme, Paris; ednoel p 10;

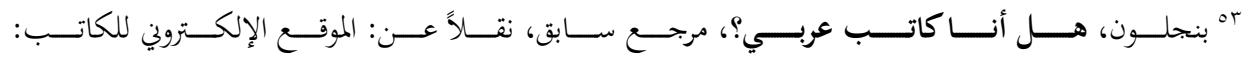

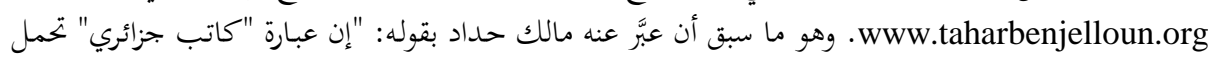

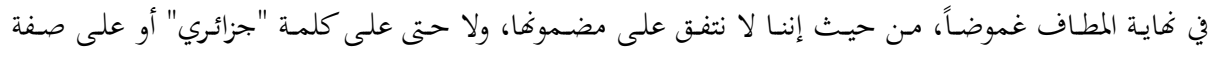

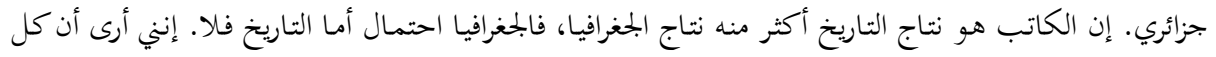

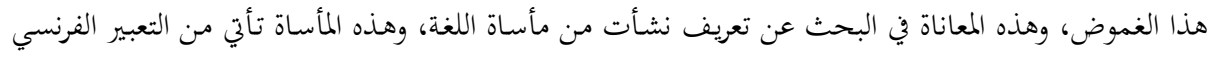
لكتاباتنا." انظر:

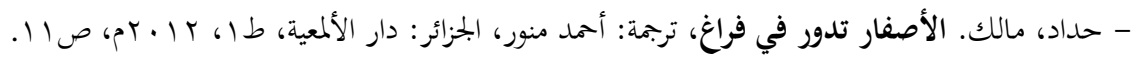
\&ْ المرجع السابق. 


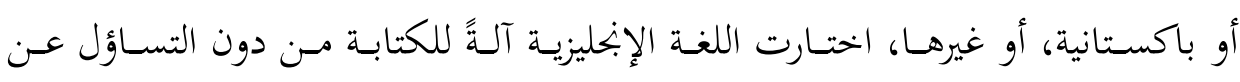
انتمائها الأصلي.

ولكن، بالنسبة إلى المغربيين، فقبولمم الثقافةَ الفرنسية يصل حدّ الاستحالة مـا دام

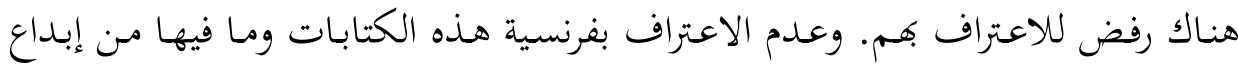

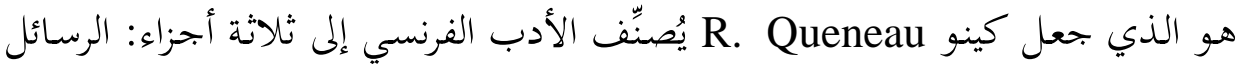

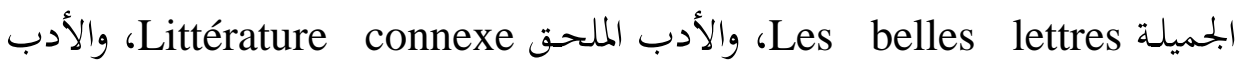

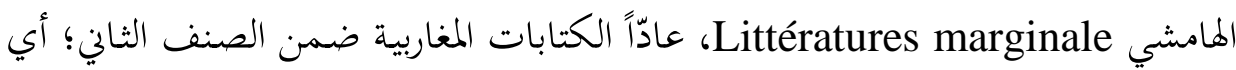

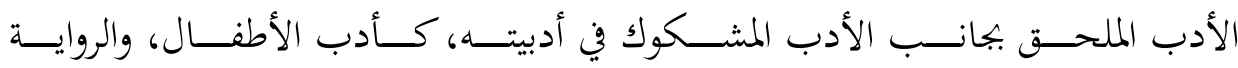

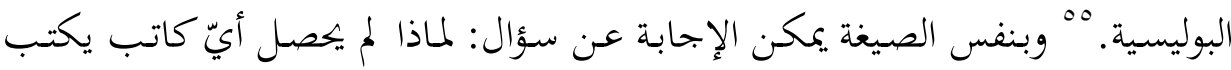

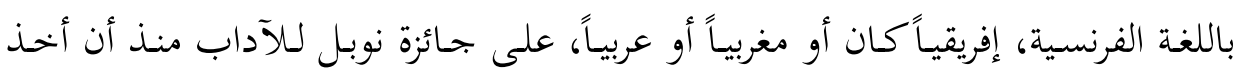

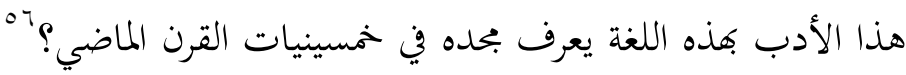

أمّا الداخل العربي والمغربي فيردّ عليه الطاهر بنجلون بخطاب العجز عن الإبداع بلغة

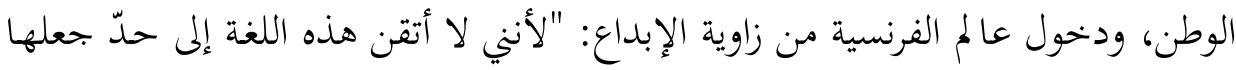

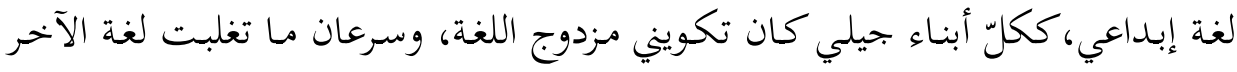

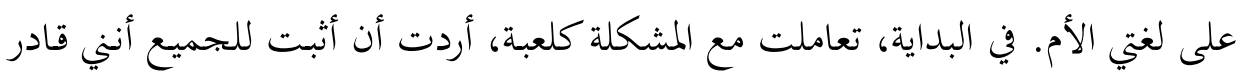

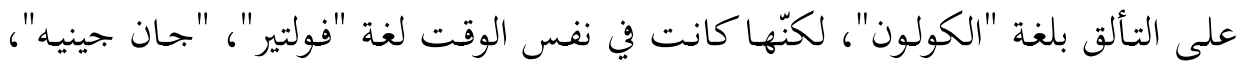

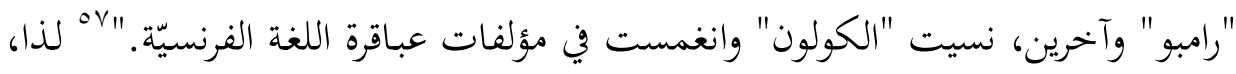

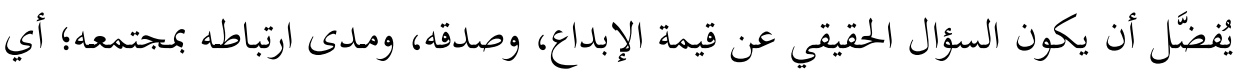
أدبية الكتابة لا هويتها، وإبداعها لا جغرافيتهي عن فيدة الإبلاع.

من هذا المنطلق كانت المنافحة عن الكتابة بلغة الآخر اختياراً إبداعياً، لا خطاباً

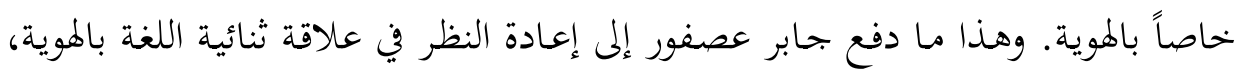

${ }^{55}$ QUENEAU, Raymond. Histoire des littératures, Paris, Gallimard, 1958, p 1397.

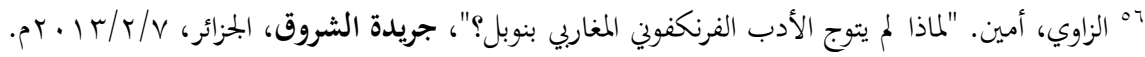

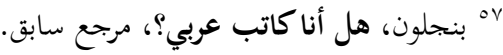




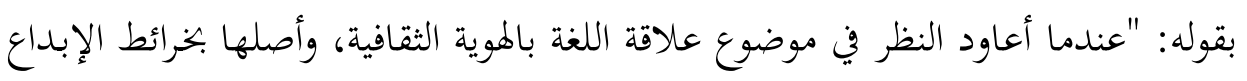

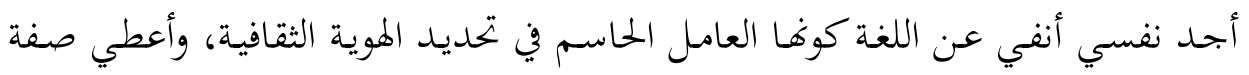

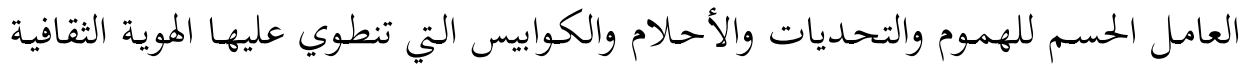

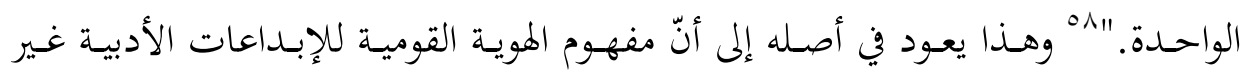

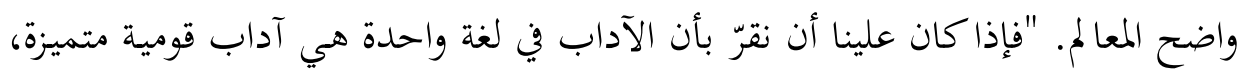

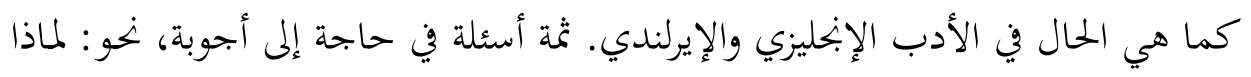

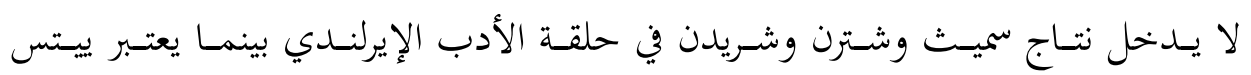

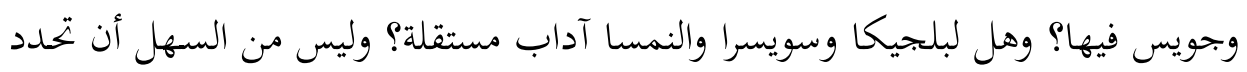

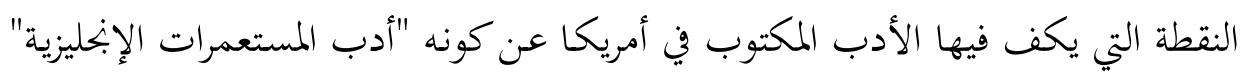

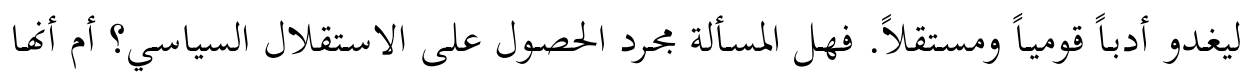

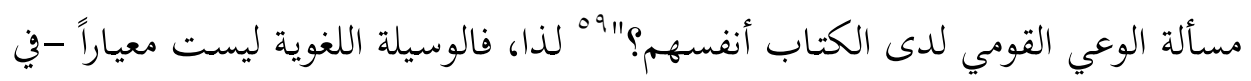
نظر المنافحين- لإضفاء الشرعية على انتماء الموية.

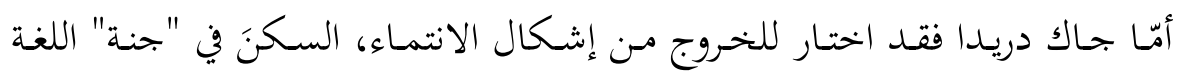

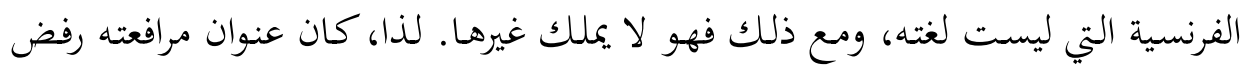

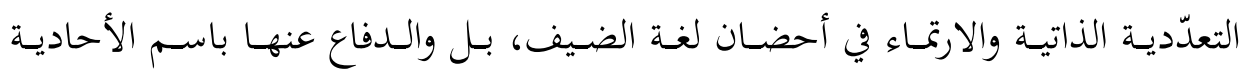

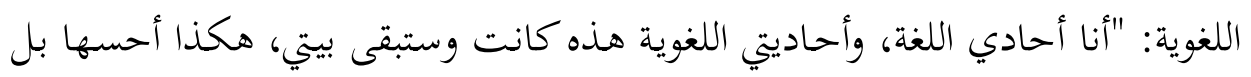

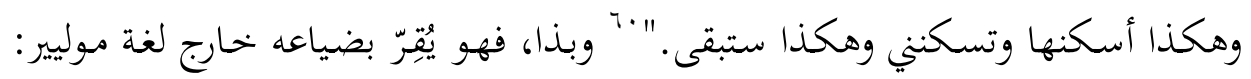

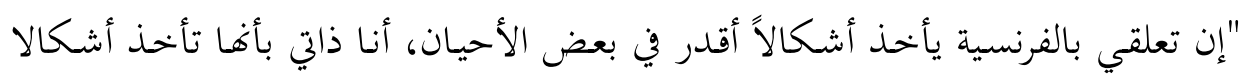

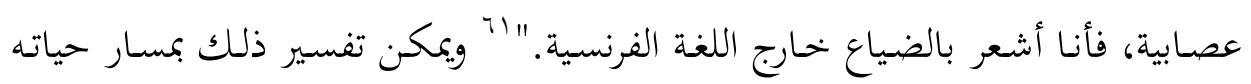

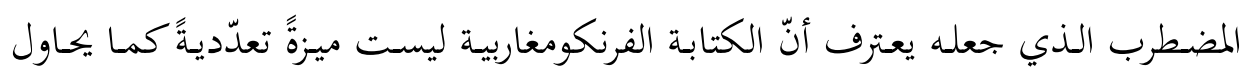

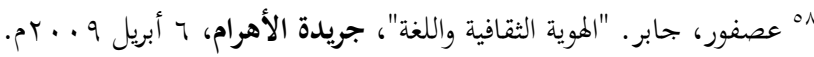

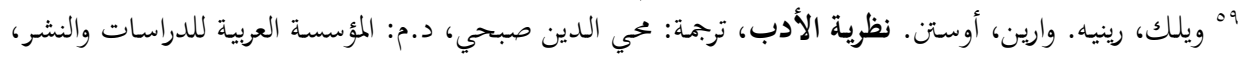

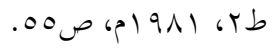

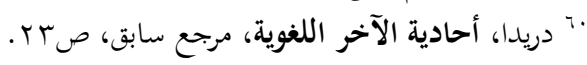

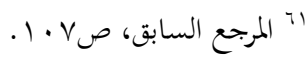




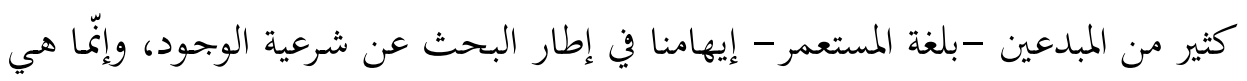

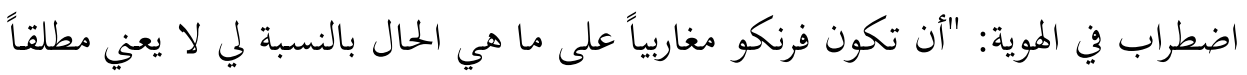

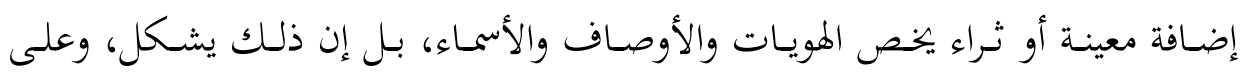

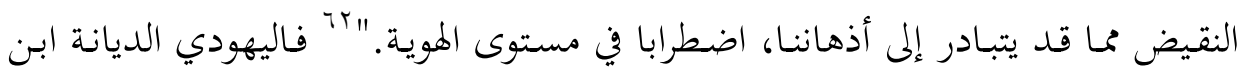

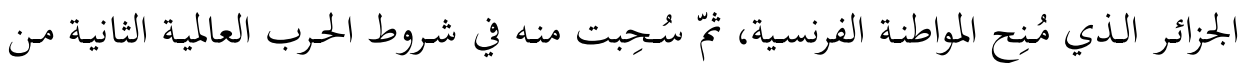

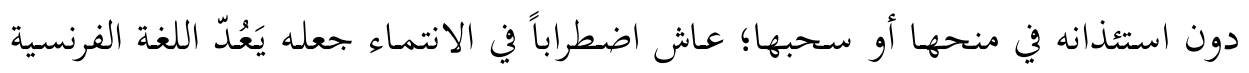

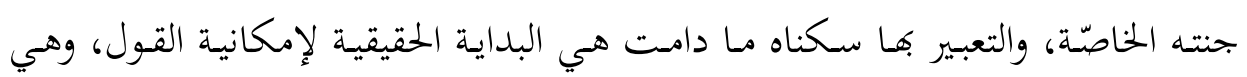

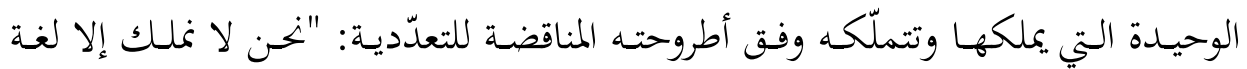

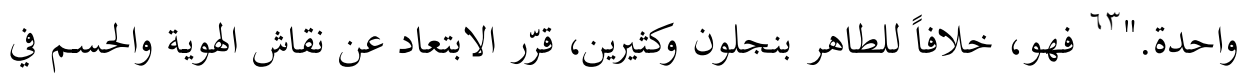

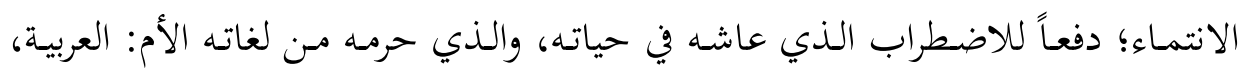

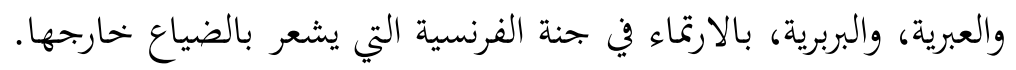

\section{رابعاً: الإبداع والوعي الشقي: قراءة تراتبية}

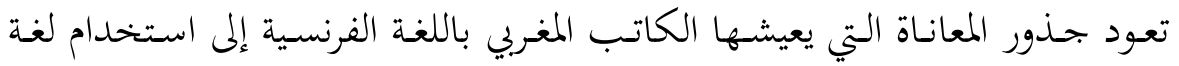

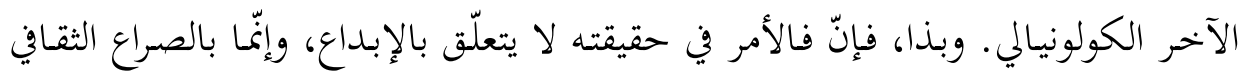

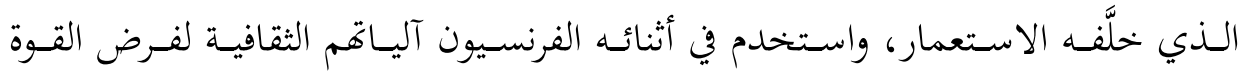

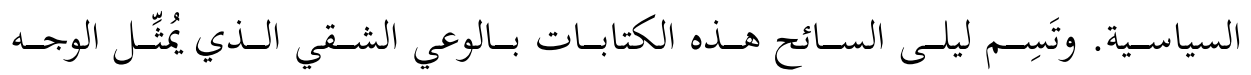

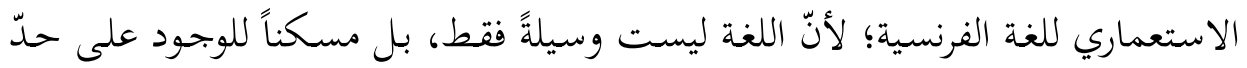

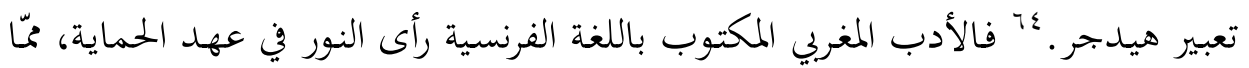

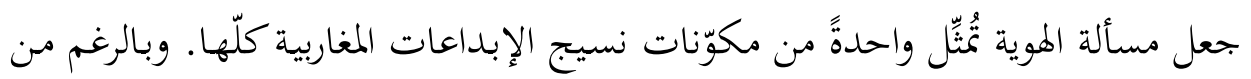

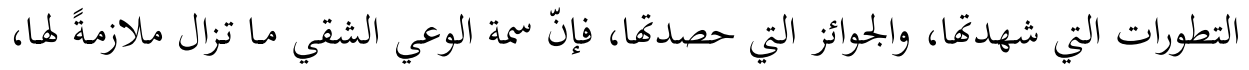


وما زالت تَطرح حتى اليوم إشكالية تصنيف نصوص الكُّاب الذين يكتبون بالفرنسية؛

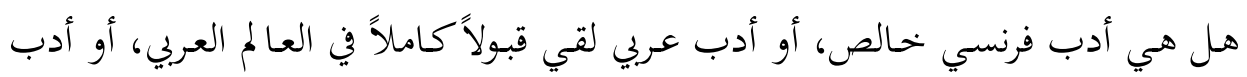

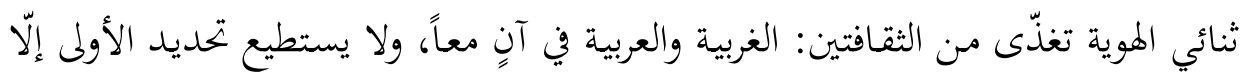
بالثانية، والحضور الإيديولوجي هو الذي يُحتِّم عليه تحديد قوميته أو هويته العربية؟ وتلـك هـي حالـة الاغـتراب الـتي أشـار إليهـا الخطيسي، وبحلّت في سـيطرة جـسنس

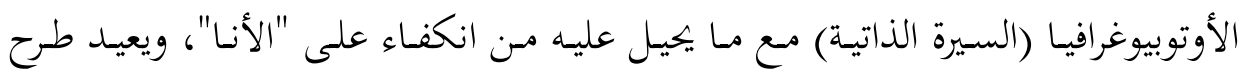

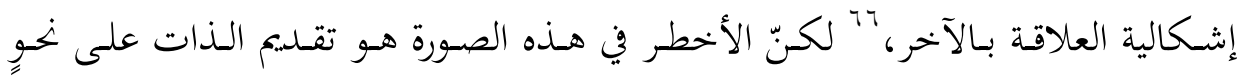
غـرابئي وفلكلموري؛ بالإصـرار على تحويل الثقافـة المحليـة إلى "صـندوق عجائـب"، وتقـلديم

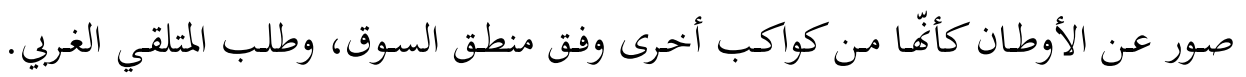

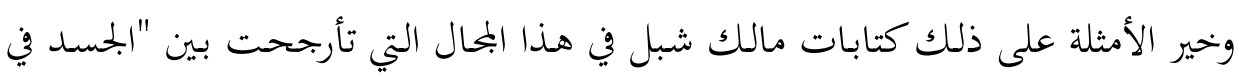

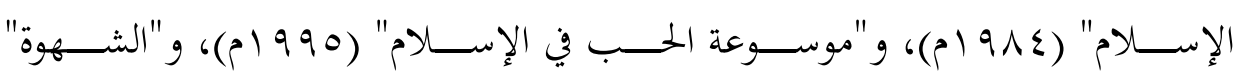

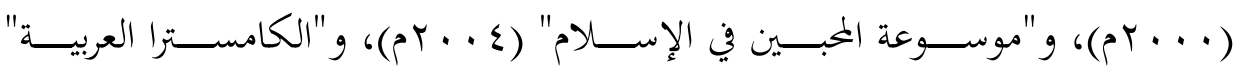

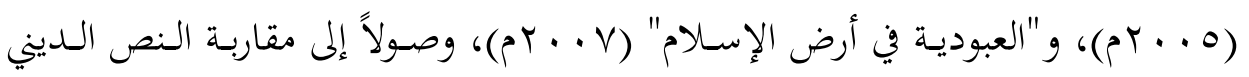
وترجمته.

أمّا في الأدب فنجد فؤاد العروي يحرص على تصوير الذات بزوايا الانحلال والفحش

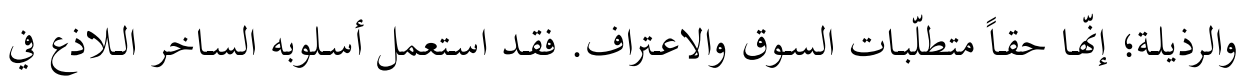

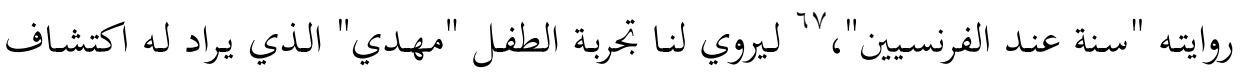

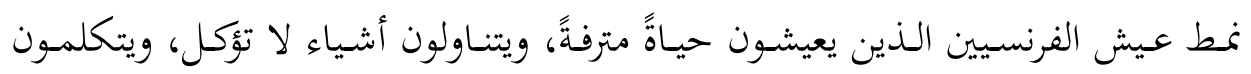

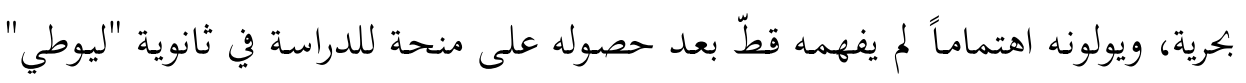
بالبيضاء؛ إنّه الوعي الشقي. أمّا عبد الله الطايع فقد اختير مرّتين للحصول على جحائزة

65 BONN, Charles. La situation Algérienne et conscience nationale. Après l'indépendance. Paris, Notre librairie, n ${ }^{\circ}$ 85, Oct-Déc 1986.- p. 36.

${ }^{67}$ Fouad, laroui. une année chez les français, Paris ; Julliard.

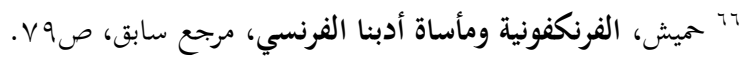


"رينودو" الفرنسية، وكلّ أعماله مستوحاة من بتربته وحياته التي عاشها بوصفه عربياً لوطياً

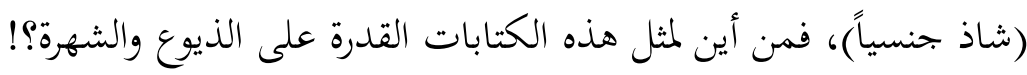

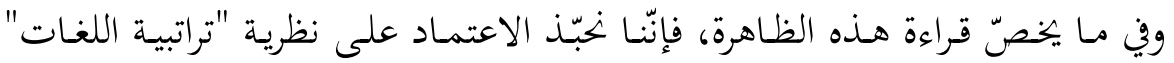

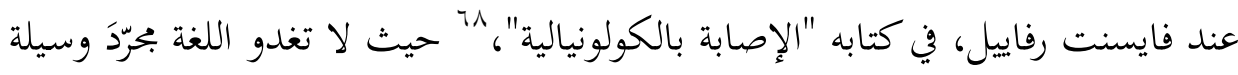

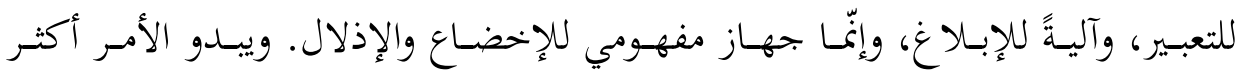

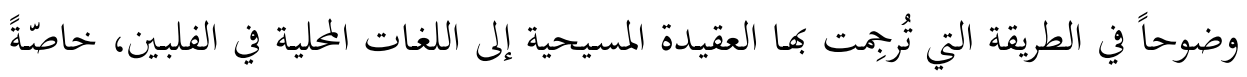

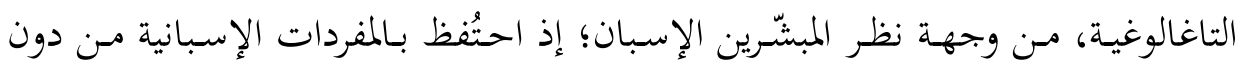

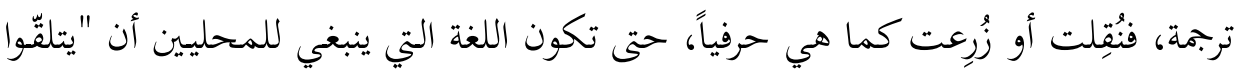
بها كلمة الربّ ويعودوا إليها".

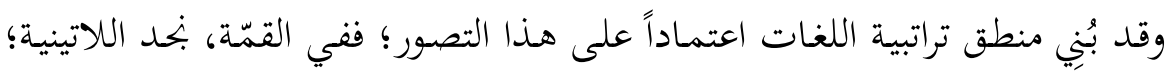

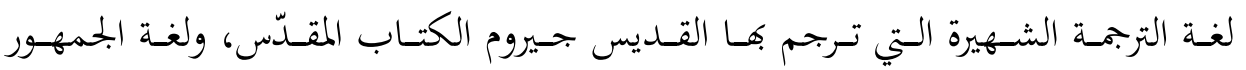

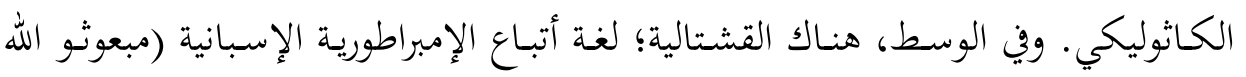

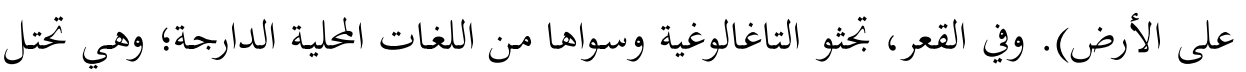

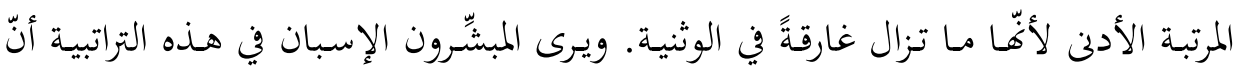

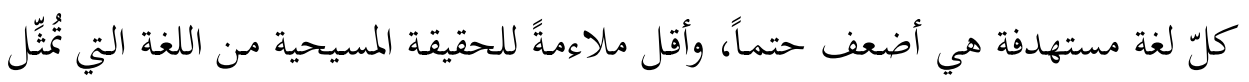

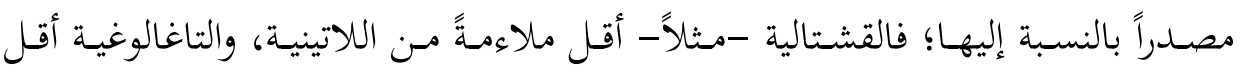

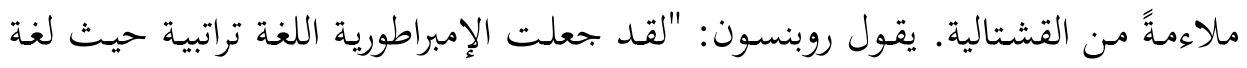

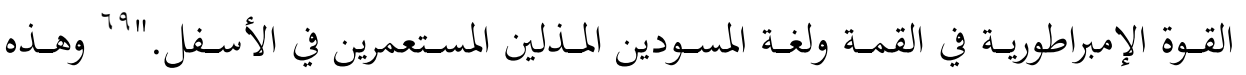

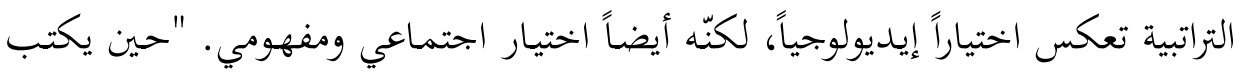

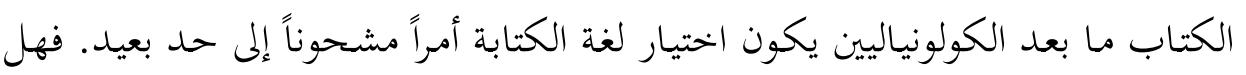

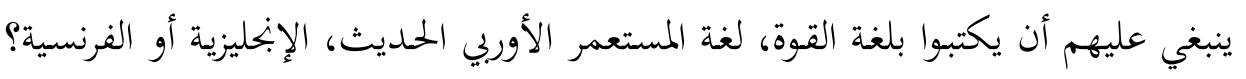

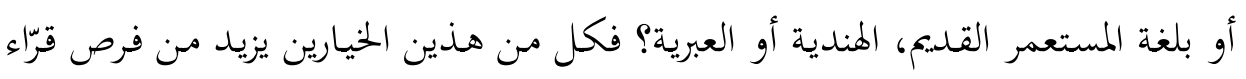

${ }^{68}$ Vicente L. Rafael. Contracting Colonialism: Translation and Christian Conversion in Tagalog Society Under Early Spanish Rule, Mar 1, 1988.

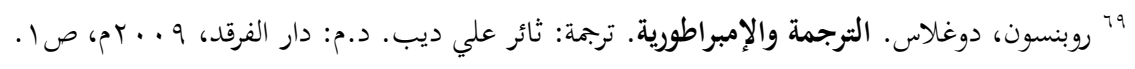


الكاتب بين قرّاء يتعدون حلقة قرائه المحليين الصغيرة، وكل منهما يمكن أن يفضي أيضاً

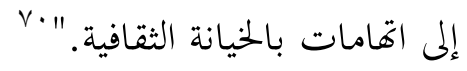

وقد أبانت دراسات ما بعد الكولونيالية أنّ التجارب الثقافية جميعاً تولد من تقاطع

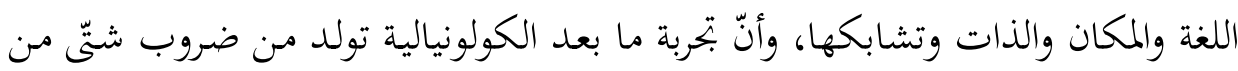
بَذْرِ الاضـطراب في تلـك التقاطعـات، ونـزع اسـتقرارها؛ ذلـك أنّ الكولونياليـة تشـــل الانتقالَ من مكان إلى آخر، وأشكالاً من "الانخلاع " يمكن أن تكون ماديةً أو ثقافيةً؛ كأن تُضطهد ثقافة معيّنة من ثنقافة يُزْعَم أفّا أرقى فلا تعود تشعر أفّا في موطنها، حيث

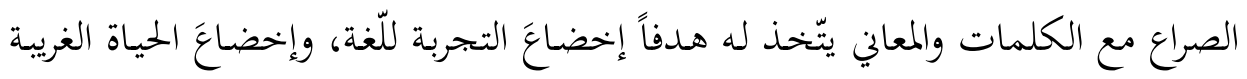
لإنسان المستورَد.

واعتماداً على مفهوم التراتبية هذا، يمكن القول إنّ الكتابة بالفرنسية ليست اختياراً

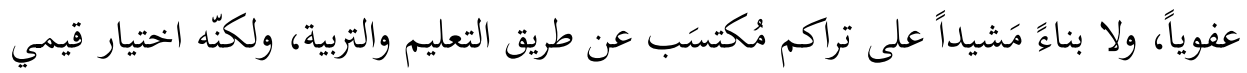

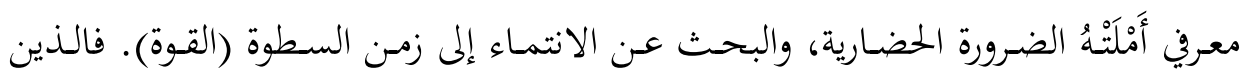
نافحوا عن شرعية هذا الأدب، محاولين الفصل بين هويته ولغته، كانوا يبحثون القضية في

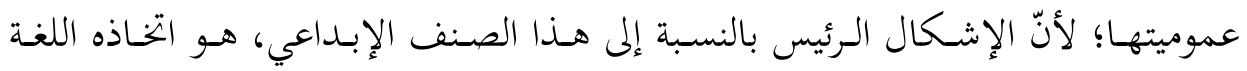

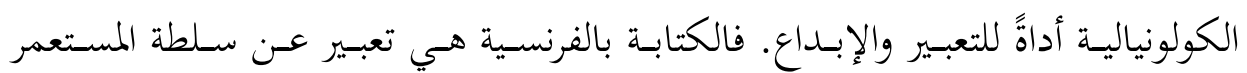
الكامن فينا، الذي يمكن رفضه سياسياً وعسكرياً، لكنّ حضوره المعرفي والفكري يأخحذ

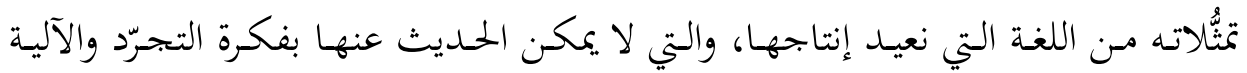
التواصلية ما دامت كلّ لغة هي تعبير عن منظومة قيمية، وبتسيد لسلطة معرفية وانتماء

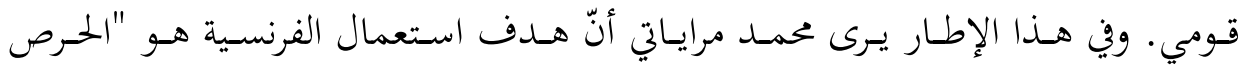

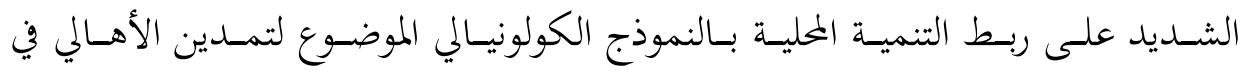

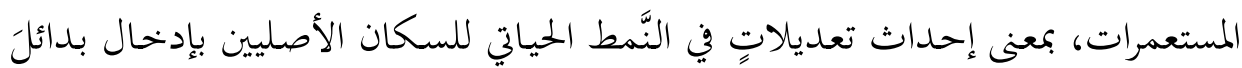

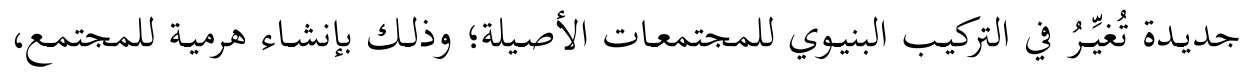




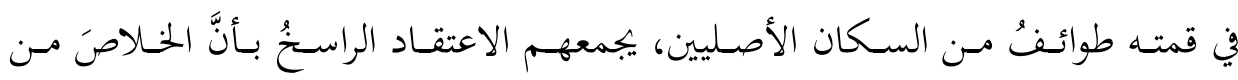

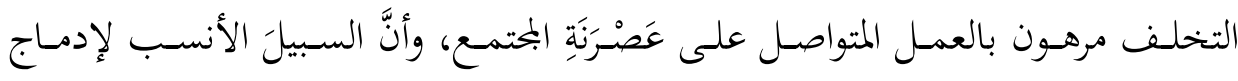

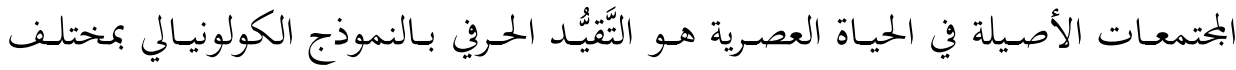

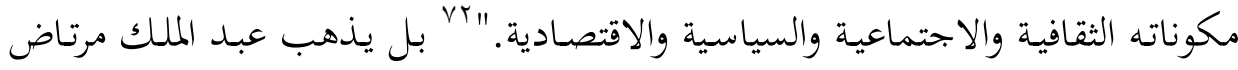

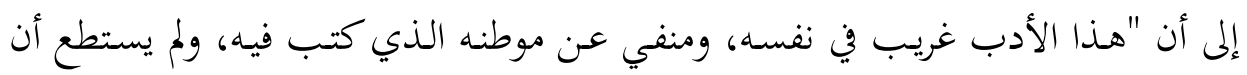

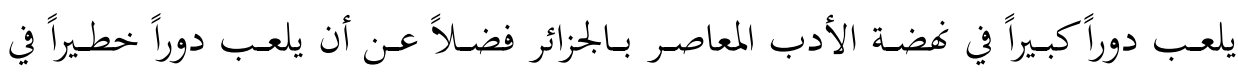

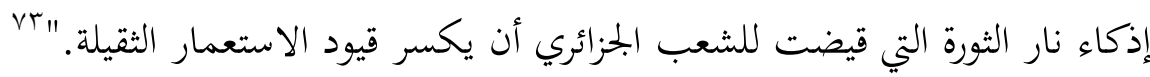

يُـذكر أنّ رشـيد بوجـدرة قـد عـاد إلى الكتابـة باللغـة العربيـة صـادحاً: إنّ استغلال

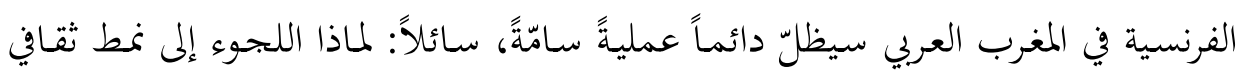

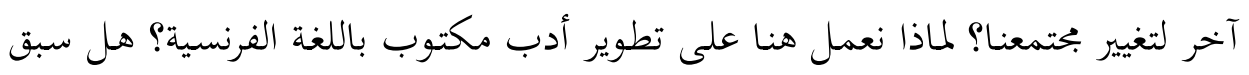

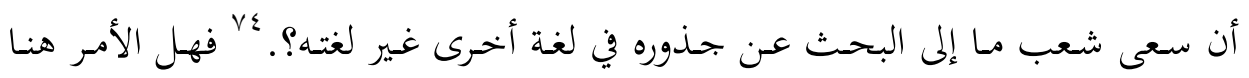
خيار؟

قد بند الجواب حين نربط هذا الصنف القولي بمنظومة الفرنكفونية التي اتخذت طابعاً

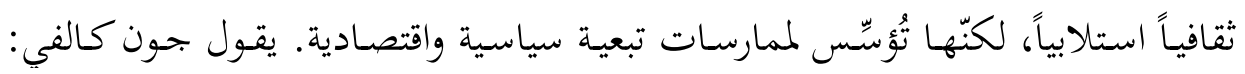

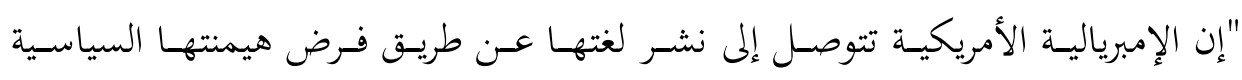

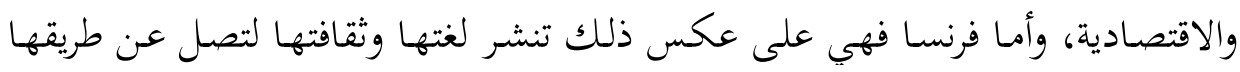

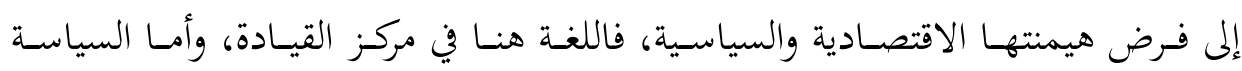

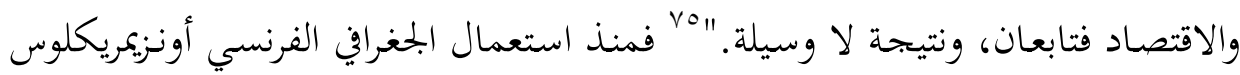

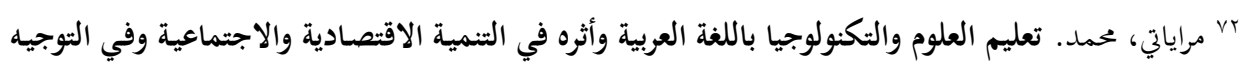

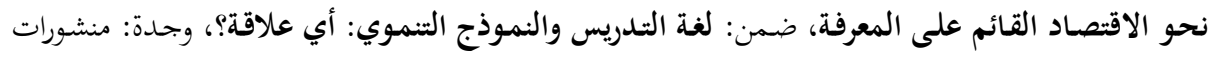

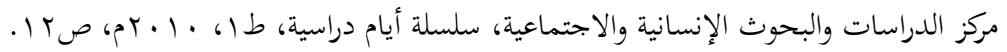

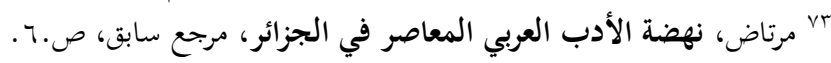

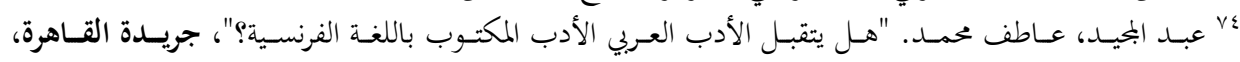
. T. Tr/O/1

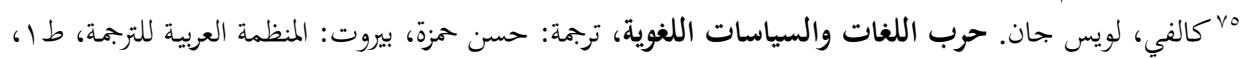

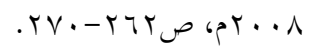




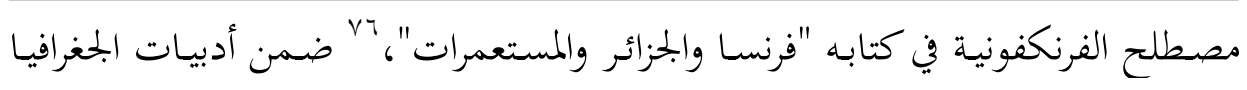

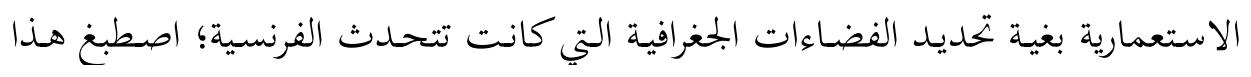

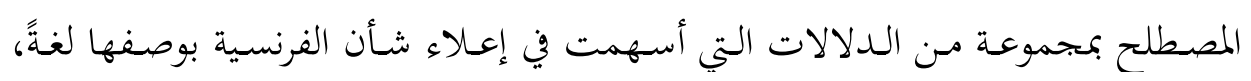

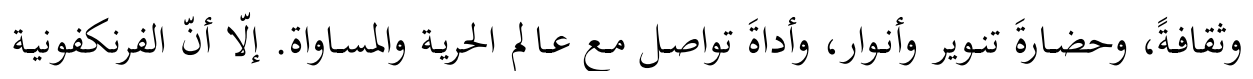

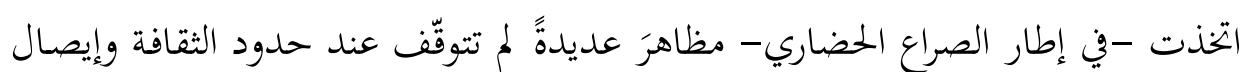

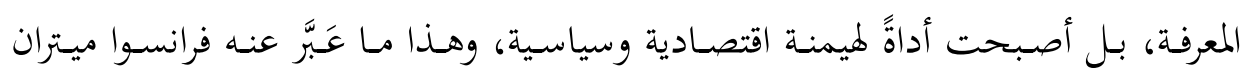

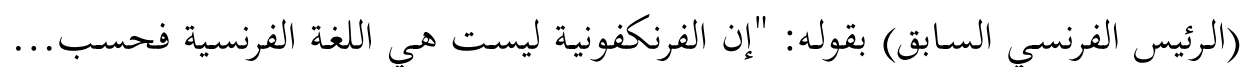

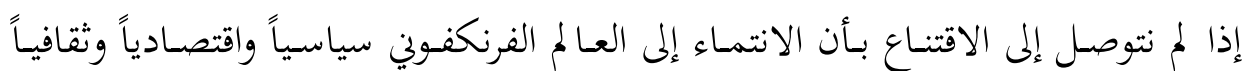

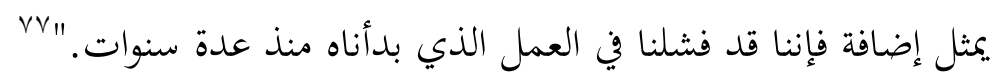

وهذا الاعتراف، وإن جاء متأخراً، يُّبِتِ أنّ ما يزعمه دعاة الفرنكفونية الفرنسيون

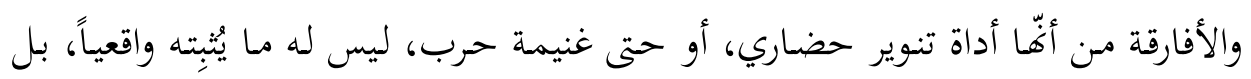

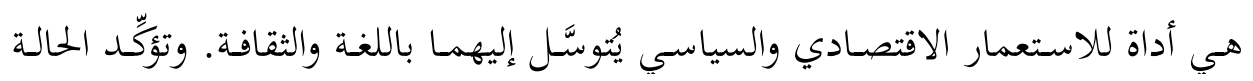

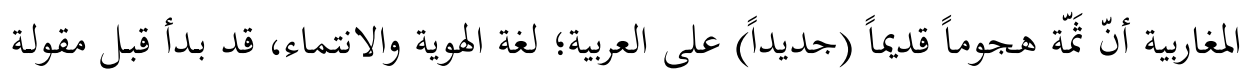

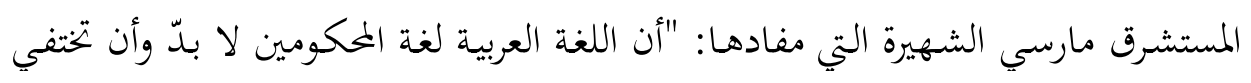

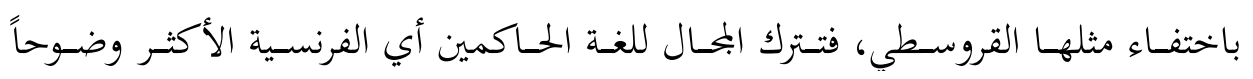
وبخاعة.

ففي الوقت الذي تطالب فيه الأصوات الفرنكفونية بحماية لغتها من وجه الطوفان

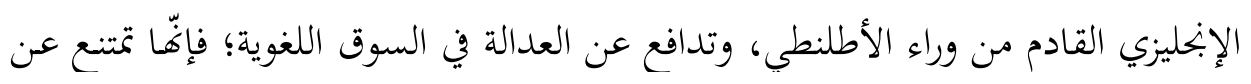

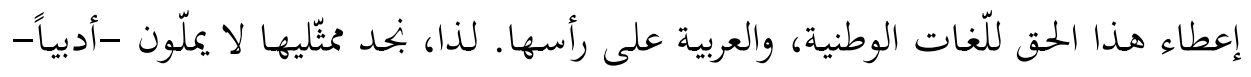

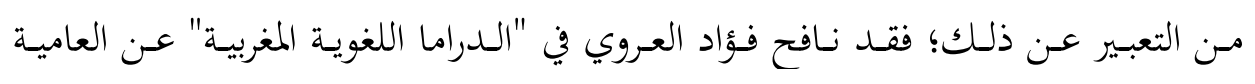

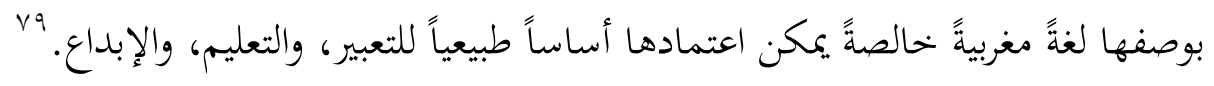

${ }^{76}$ Onésime Reclus France, Algérie et colonies ; imprimerie Lahure ; Paris.

${ }^{77}$ François Mittérand ; Le Monde ;9/02/1989.

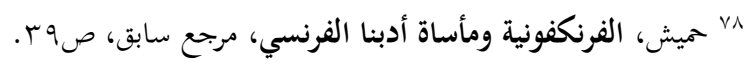

${ }^{79}$ Laroui, Fouad. Le Drame linguistique marocain, Zellige, 2011, 


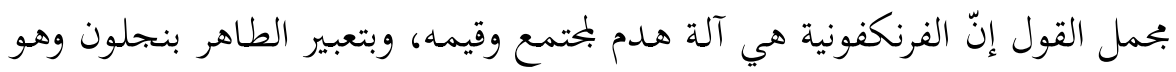

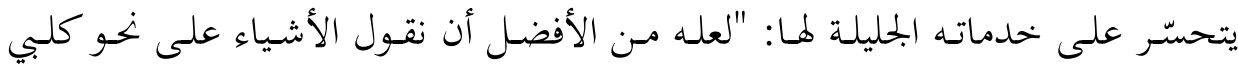

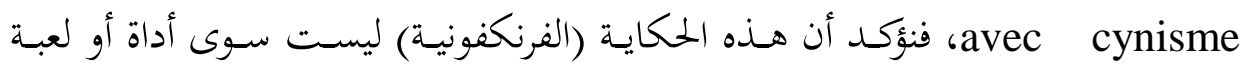

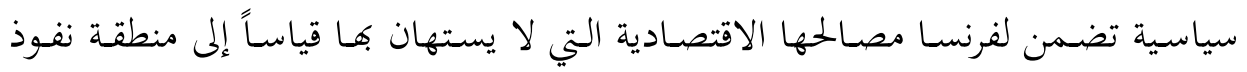

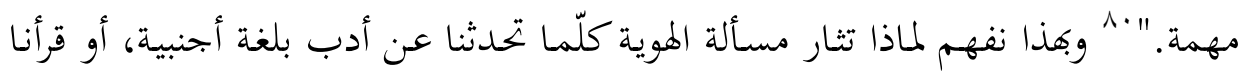

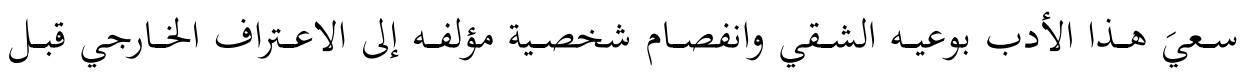

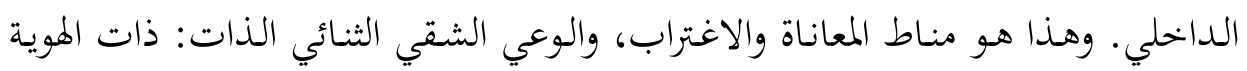
والانتماء الوطني، وذات الكونية والانتماء الفرنكفوين.

\section{خامساً: الإبداع بين سلطة اللغة وسلطة المتلقي}

إنّ التوظيف الإيديولوجي والثقافي لمعطيات الذات في جلب القرّاء بحثاً عن رضاهم

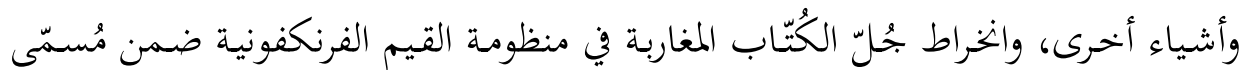

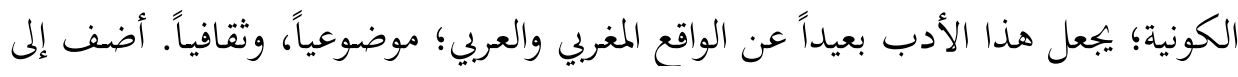

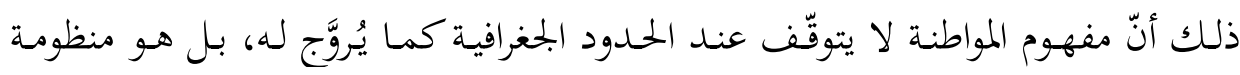

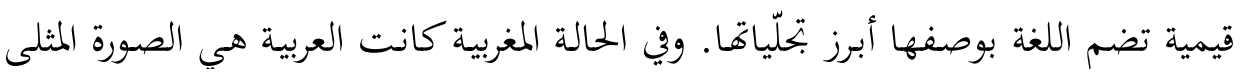

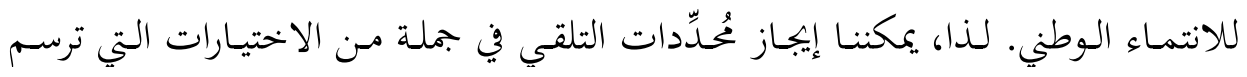

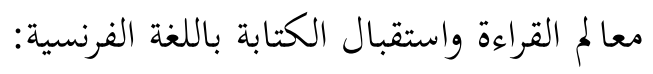

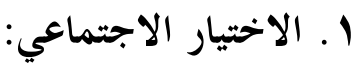

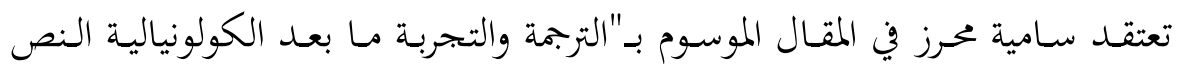

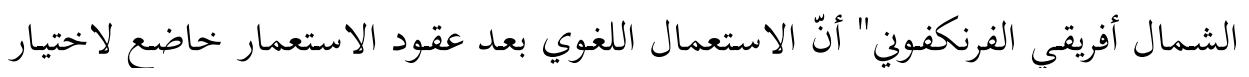

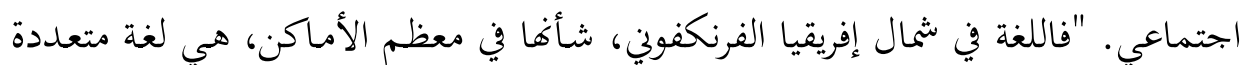

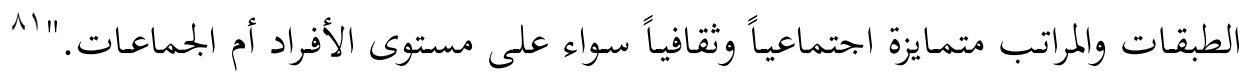


وتستدل على ذلك بمقولة عبد الكبير الخطيبي: "اللهجة المغربية التي يتكلم بها في البيت،

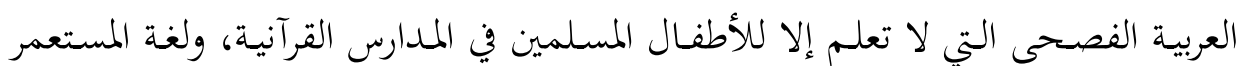

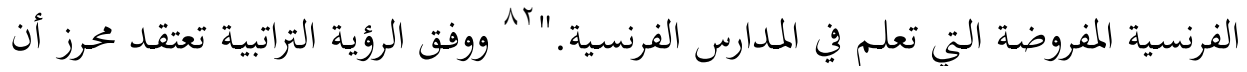

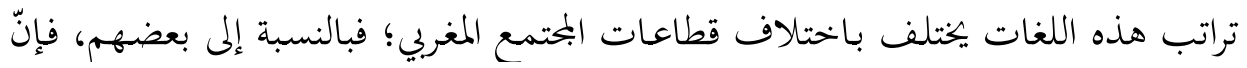

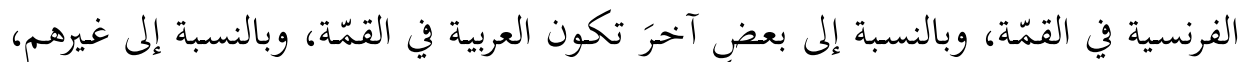

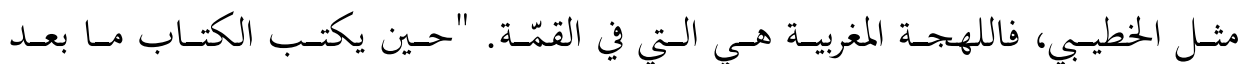

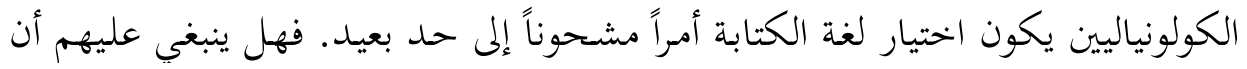

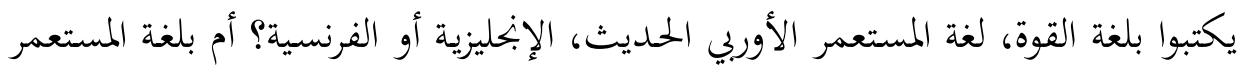

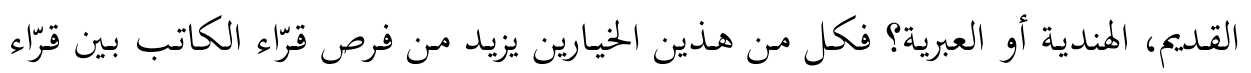

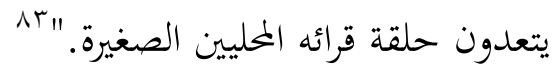

إنّ الاختيار اللغوي هـو اختيـار إيـديولوجي اجتمـاعي يرتبط بانتمـاء طبقي في حـد

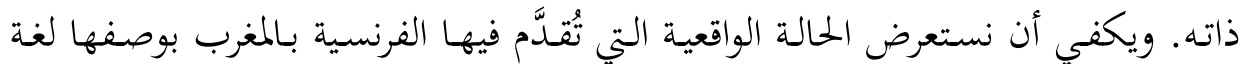

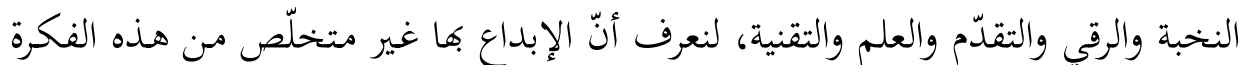

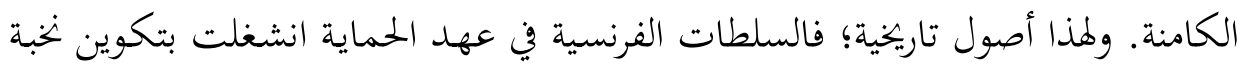

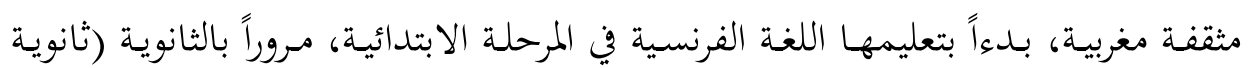

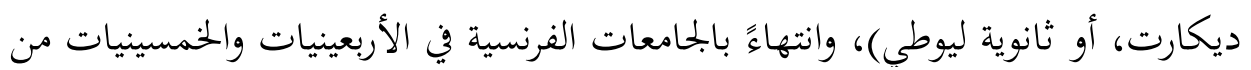
القرن الماضي.

وعلى كلّ حال، فإنّ أبناء العائلات البرجوازية الحضرية الذين اكتسبوا تعليماً نخبوياً

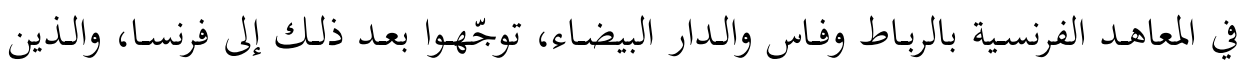

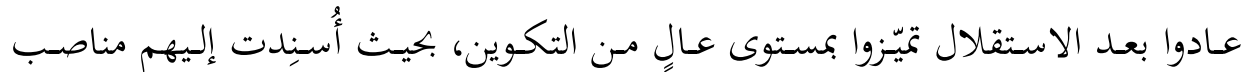

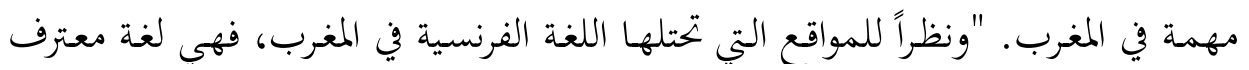

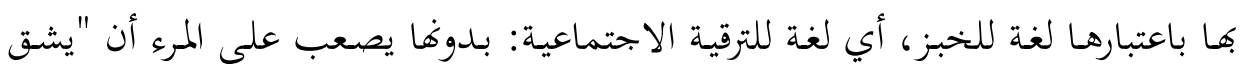

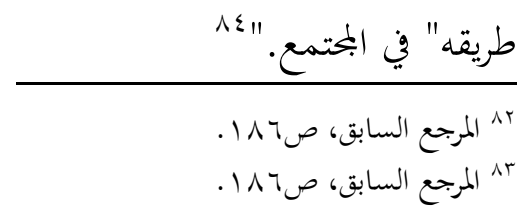

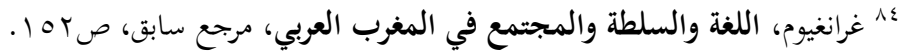




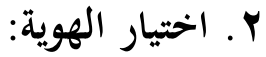

يخضع الاختيار بين نموذجين تواصليين لاعتبارات ذات صلة بالهوية، ولقيم معرفية

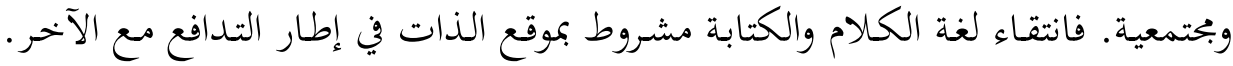

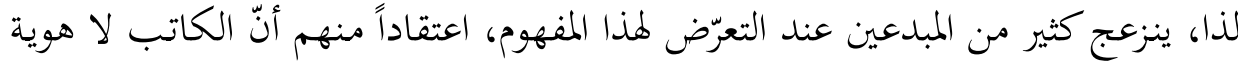

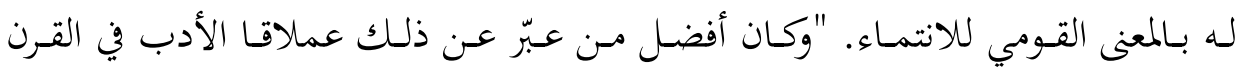

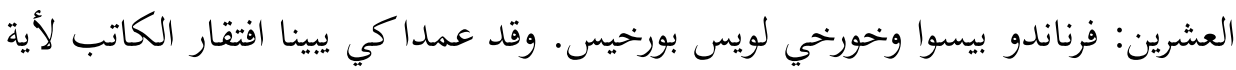

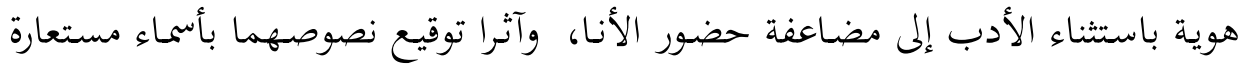

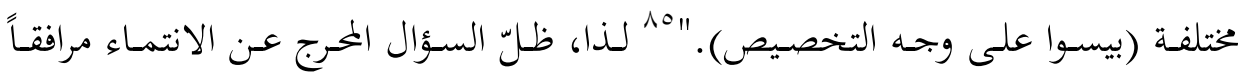

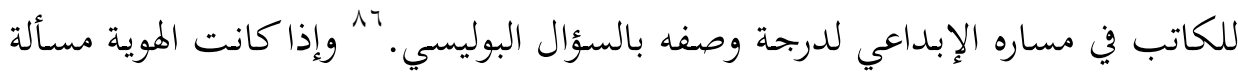

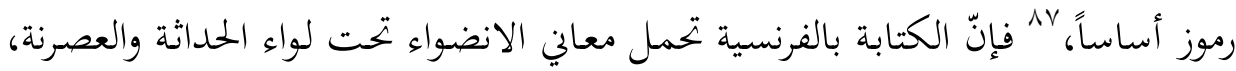

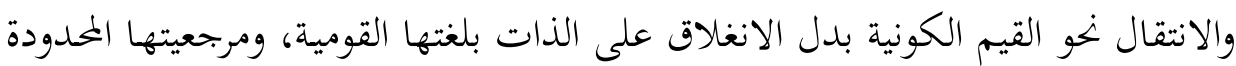

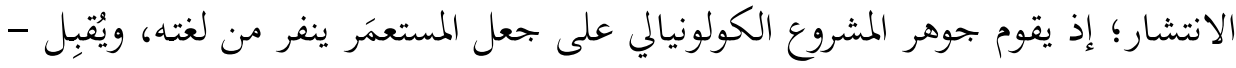

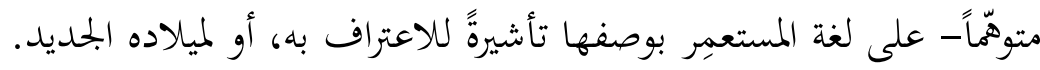

وفي هذا السياق الاستعماري الجديد "تصبح اللغة الوسيط الذي يجري من خحلاله

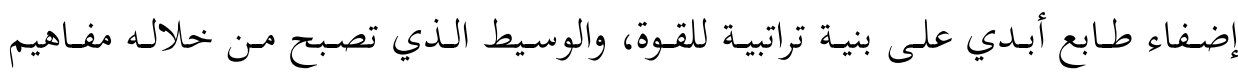

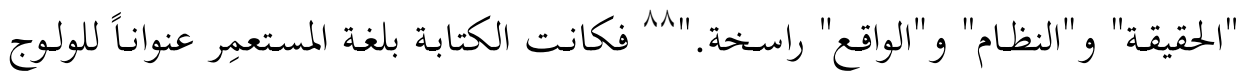

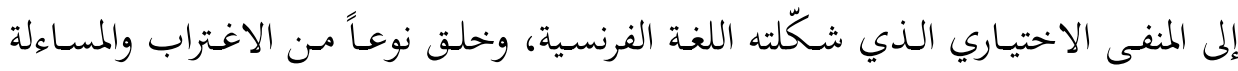

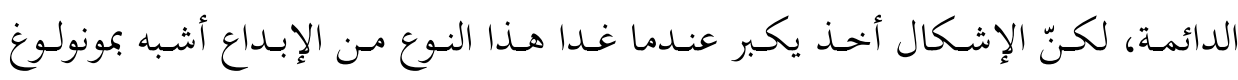

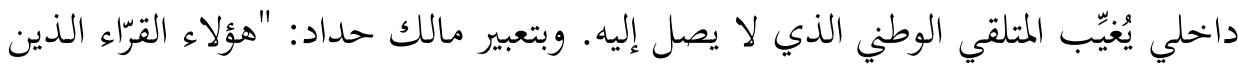

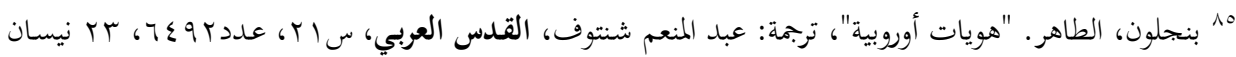

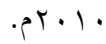

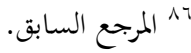

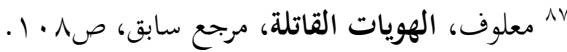
^^ اشكروفت، بيل وآخرون. الرد بالكتابة النظرية والتطبيق في آداب المستعمرات القديمة، ترجمة: شهرت العالم،

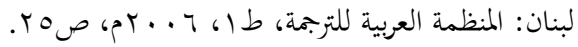




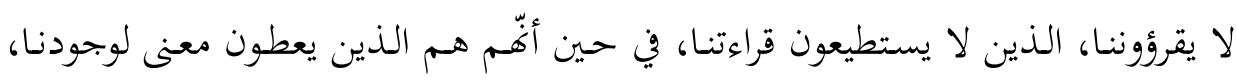

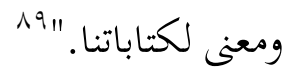

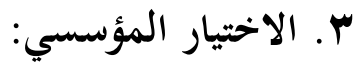

الإبداع بضاعة، وقليل من المبدعين مَن يريد الإقرار بهذه الحقيقة التي تُدخِل النص

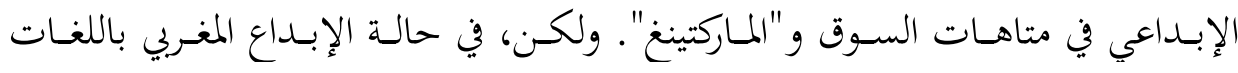

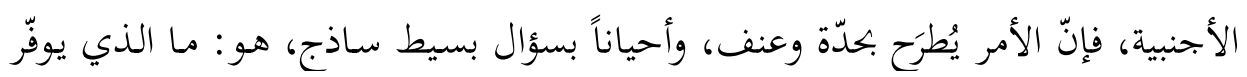

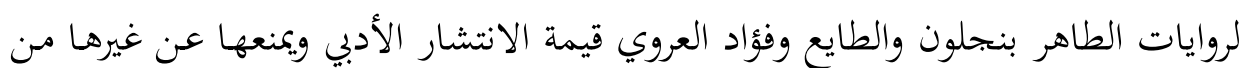

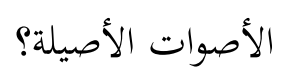

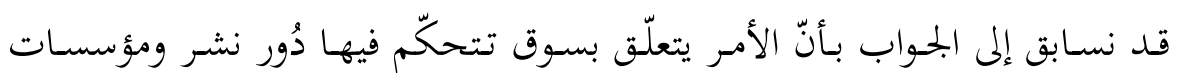

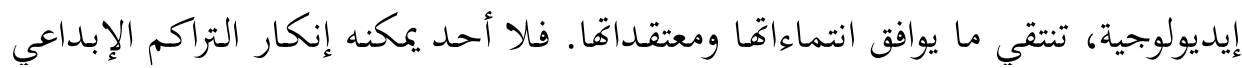

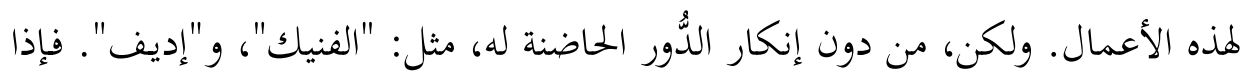

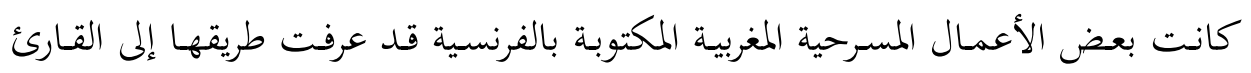

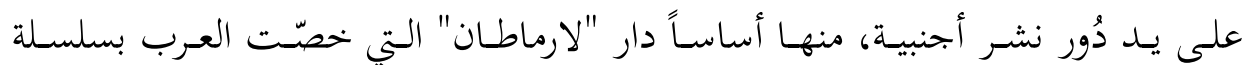

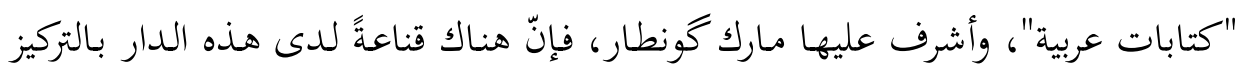

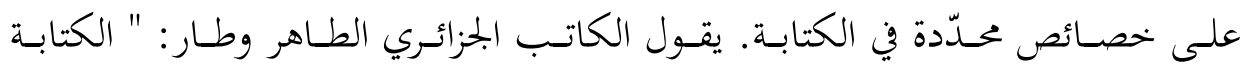

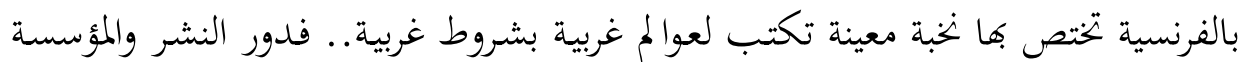

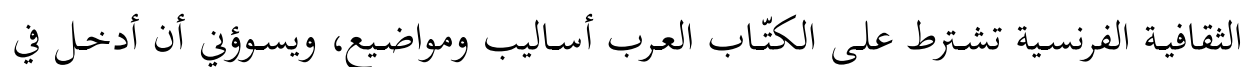

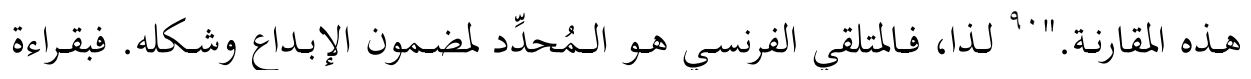

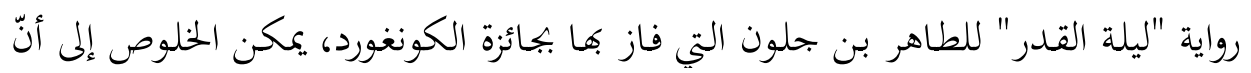

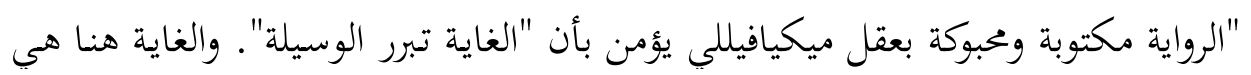

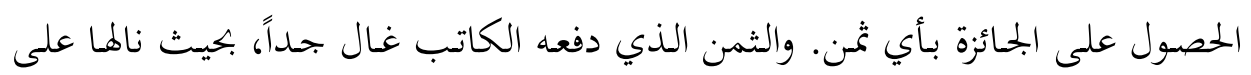

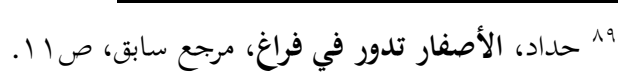

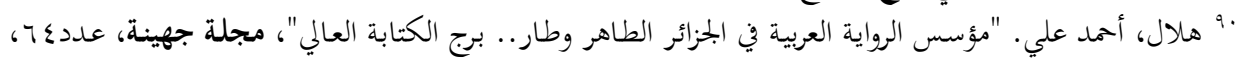


حساب التعريض بعدد من القيم الروحية، والأخلاقية، والاجتماعية الإسلامية العزيزة على

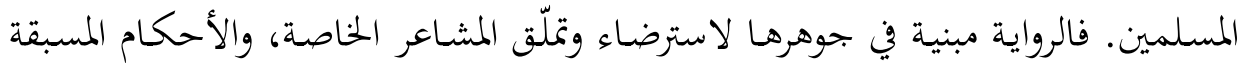

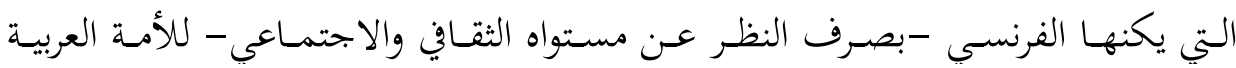
والإسالامية. وهي مشاعر صليبية ترقد هامدة تحت سطح رقيق من النفاق العنصري، لا لا

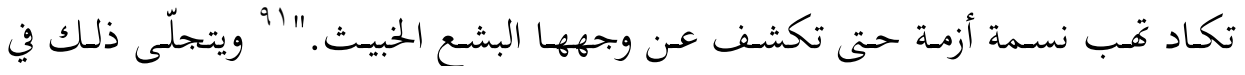

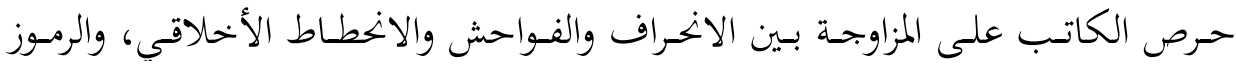

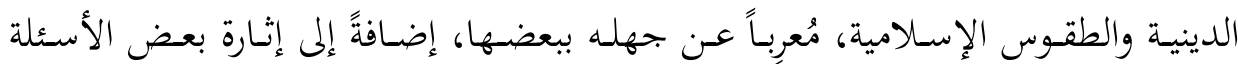

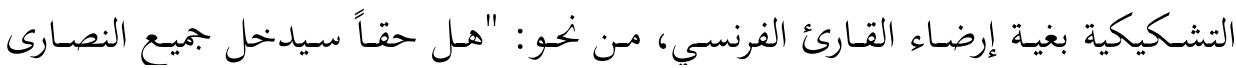

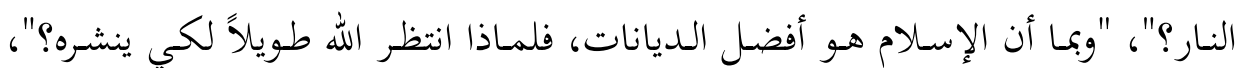

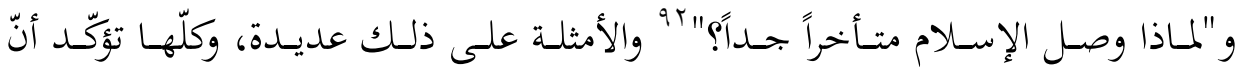
الكاتب كتب روايته واضعاً نُصب عينيه السيد الفرنسي، وكيفية استقباله لطروحاته. يُذكَر أنّ ابـن جلون سـار على خطى إدريس الشـرابي الــي كتـب روايـة "الماضي

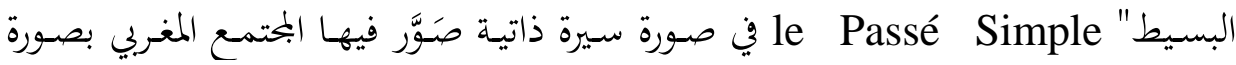

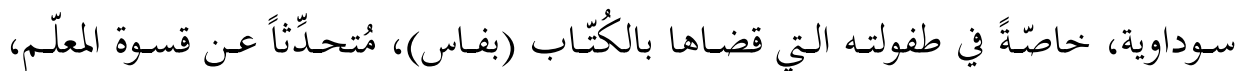

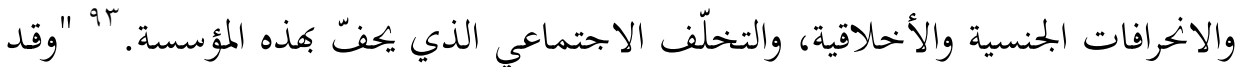
أعطت هـذه الروايـة آنذاك، ذخهيرة سياسية حية لليمـين العنصـري الاستعماري الفرنسي الذي كان يطالب بتمديد فترة الحماية للمغرب بحجة أن (فرنسا) لم تتم رسالتها الحضارية

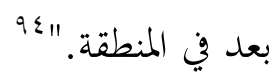

وتأسيساً على ذلك، فالنصـوص التي توافـق رؤيـة الماكنـة الفرنكفونيـة تُحـدِّد سـلفاً

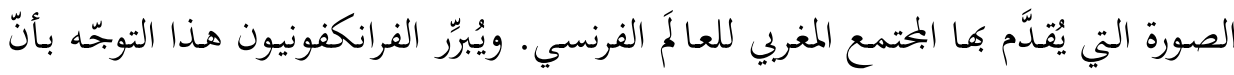
ا9 البقالي، أحمد عبد السلام. "رواية "ليلة القدر" تملق للمشاعر الصليبية"، مجلة دعوة الحق، عدد. VY، ديسمبر r Pr بنجلون، الطاهر. ليلة القدر، ترجمة: محمد الشرقي، مراجعة: محمد بنيس، المغرب: دار توبقال، الطبعة، 9NVV 9๕ Chraibi Driss, le Passé Simple;paris 1986 Folio. ص صنو.09. ؛9 البقالي، رواية "ليلة القدر" تملق للمشاعر الصليبية، مرجع سابق، صهـ. 


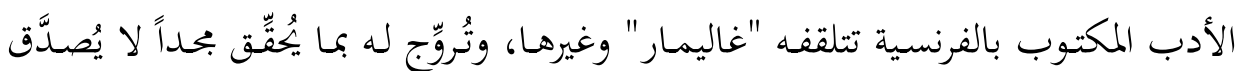

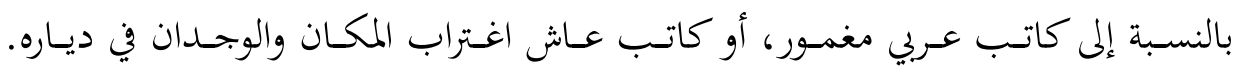

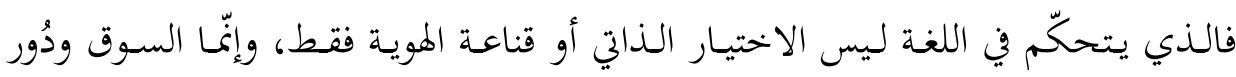

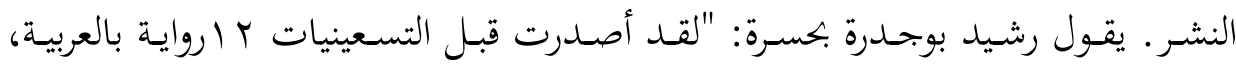

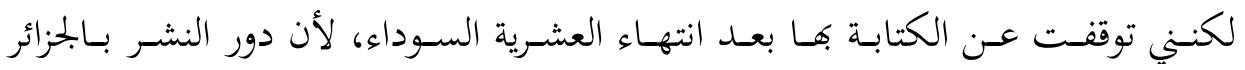
تدهورت، خاصة بعد انسحاب الدولة."

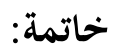

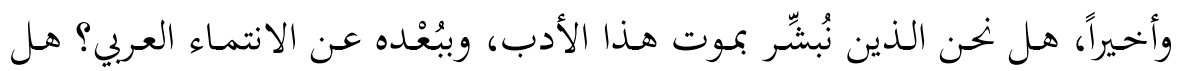

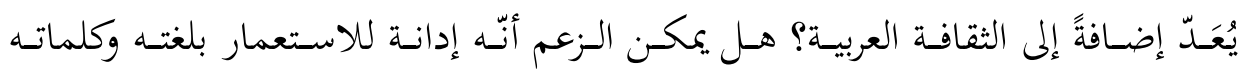

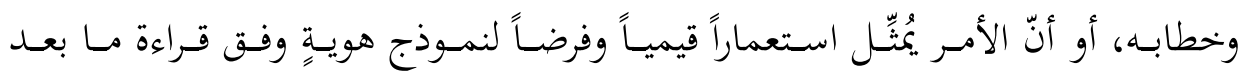
الكولونيالية؟

"الأدب المغربي المكتوب باللغة الفرنسية أصبح يلامس قضايا وموضوعات تنطلق من

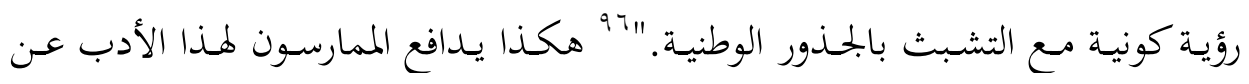

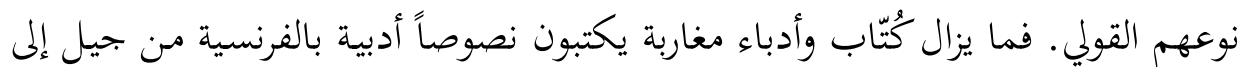

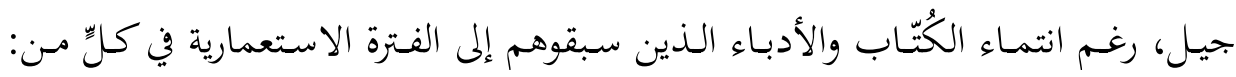

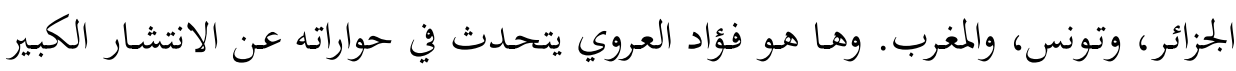
لهذا الإبداع.

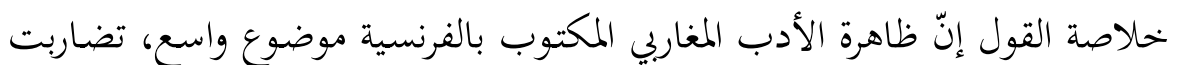

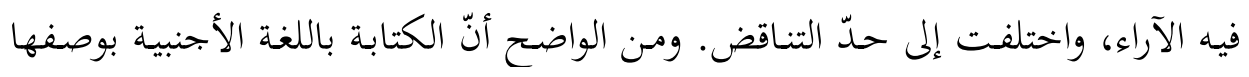

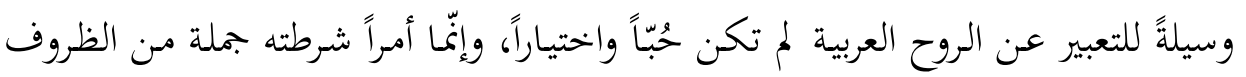

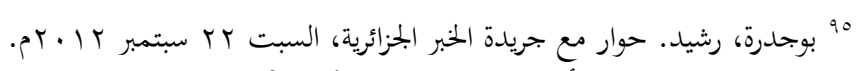

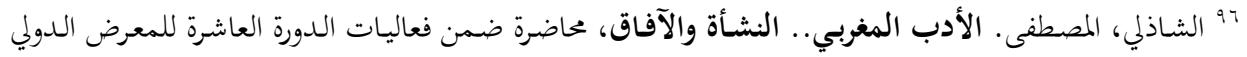


القاهرة، لكنّه -في الوقت نفسه- تعبير عن منظومة قيمية معيّنة، ميّا جعله مشروطاً بأزمة الشرعية، والبحث الدائم عن الوجود. وبناءً على مفهوم تراتبية اللغات الذي اقتبسناه من

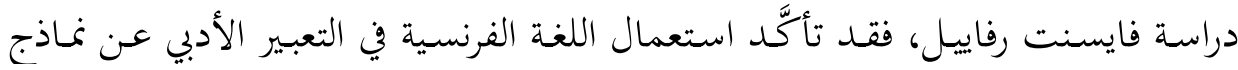

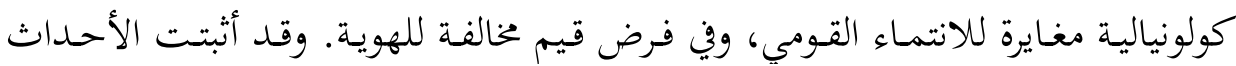

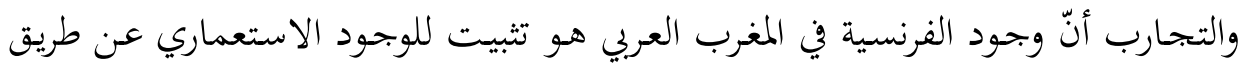

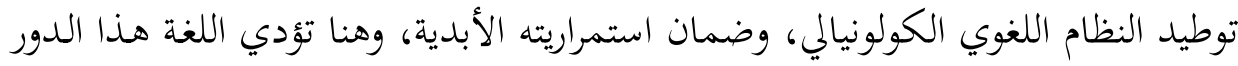
الخطير في إبراز الطابع الهيمني لهذا النظام، القـائم على تراتبيةٍٍ للقوى، مقابل النظر إلى

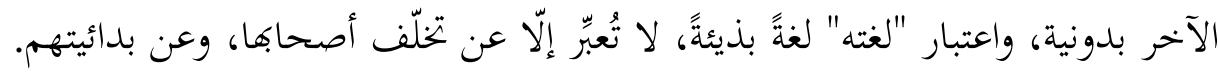

